\title{
Ground-based FTIR and MAX-DOAS observations of formaldehyde at Réunion Island and comparisons with satellite and model data
}

\author{
C. Vigouroux ${ }^{1}$, F. Hendrick ${ }^{1}$, T. Stavrakou ${ }^{1}$, B. Dils ${ }^{1}$, I. De Smedt ${ }^{1}$, C. Hermans ${ }^{1}$, A. Merlaud ${ }^{1}$, F. Scolas ${ }^{1}$, C. Senten ${ }^{1}$, \\ G. Vanhaelewyn ${ }^{1}$, S. Fally ${ }^{2,}$, M. Carleer ${ }^{2}$, J.-M. Metzger ${ }^{3}$, J.-F. Müller ${ }^{1}$, M. Van Roozendael ${ }^{1}$, and M. De Mazière ${ }^{1}$ \\ ${ }^{1}$ Belgian Institute for Space Aeronomy (BIRA-IASB), Brussels, Belgium \\ ${ }^{2}$ Service de Chimie Quantique et de Photophysique (SCQP), Université Libre de Bruxelles (ULB), Brussels, Belgium \\ ${ }^{3}$ Laboratoire de l'Atmosphère et des Cyclones (LACy), Université de La Réunion, France \\ *now at: Belgian Institute for Space Aeronomy (BIRA-IASB), Brussels, Belgium
}

Received: 17 June 2009 - Published in Atmos. Chem. Phys. Discuss.: 27 July 2009

Revised: 30 November 2009 - Accepted: 1 December 2009 - Published: 17 December 2009

\begin{abstract}
Formaldehyde (HCHO) columns have been retrieved from ground-based Fourier transform infrared (FTIR) campaign measurements in 2004 and 2007 and from UVVisible MAX-DOAS measurements in 2004-2005 at the NDACC site of Réunion Island $\left(21^{\circ} \mathrm{S}, 55^{\circ} \mathrm{E}\right)$. The FTIR and MAX-DOAS daily mean formaldehyde total columns are intercompared in their common measurement period, from $\mathrm{Au}-$ gust to October 2004. The ground-based data are also compared to correlative SCIAMACHY data. The comparisons account for the vertical sensitivity differences of the data sets, by including their respective averaging kernels. Complete error budgets are also presented.

The FTIR and MAX-DOAS daily mean total columns agree very well: no significant bias is observed and the standard deviation of the comparisons is only $8 \%$. Both FTIR and MAX-DOAS HCHO total columns are in good agreement with SCIAMACHY values in the 2004-2005 period, with standard deviations of $21 \%$ and $31 \%$, respectively. The same seasonal cycle is observed by the different instruments, with a minimum in austral winter and a maximum in FebruaryMarch.

The FTIR and MAX-DOAS data are confronted with HCHO columns calculated by a global CTM, the IMAGES model. The model underestimates the HCHO columns by 23-29\% in comparison with FTIR, and by $15 \%$ in comparison with DOAS. This bias might have multiple causes, including an underestimation of $\mathrm{OH}$ concentrations in the model (as indicated by a sensitivity study using prescribed
\end{abstract}

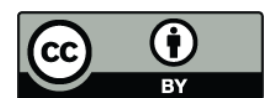

Correspondence to: C. Vigouroux (corinne.vigouroux@aeronomie.be)
$\mathrm{OH}$ fields) and/or an underestimated contribution of largescale transport of $\mathrm{HCHO}$ precursors from Madagascar. The latter hypothesis is comforted by the large observed day-today variability of HCHO columns, and by the observation that the peak values of FTIR columns can often be associated with free tropospheric transport patterns from source regions over Madagascar to Réunion Island, according to simulations performed with the Lagrangian particle dispersion model FLEXPART.

\section{Introduction}

The main sources of formaldehyde (HCHO) in the atmosphere are the photochemical oxidation of methane and nonmethane volatile organic compounds (NMVOCs). The sinks of formaldehyde are photolysis, oxidation by $\mathrm{OH}$ and dry and wet deposition (Stavrakou et al., 2009a). Due to its short lifetime of only a few hours, its global distribution closely resembles the distribution of its sources. Therefore, over land, observations of formaldehyde provide new constraints on the emissions of reactive NMVOCs (in particular isoprene), as demonstrated by several inverse modeling studies using satellite retrievals of HCHO (e.g. Abbot et al., 2003; Stavrakou et al., 2009b). Far away from the emission regions, e.g. over oceans, formaldehyde observations might provide an opportunity to test our current knowledge regarding methane oxidation, and possibly also to quantify the effect of long-range transport of NMVOCs from source regions.

Published by Copernicus Publications on behalf of the European Geosciences Union. 
Formaldehyde total columns have been observed from space by GOME and SCIAMACHY (Abbot et al., 2003; De Smedt et al., 2008; Dufour et al., 2009). Comparisons between SCIAMACHY and ground-based MAXDOAS (Multi-AXis Differential Optical Absorption Spectroscopy) formaldehyde total columns have been presented in Wittrock et al. (2006). Formaldehyde measurements by ground-based FTIR (Fourier transform infrared) instruments have been reported at mid-latitude (Demoulin et al., 1999; Jones et al., 2009) and polar stations (Notholt et al., 1997), and during a ship cruise in the central Atlantic Ocean (Notholt et al., 2000). MAX-DOAS formaldehyde campaign measurements have been performed in the Italian Po-Valley in summer 2002 (Heckel et al., 2005).

In the present work, we provide the first time series of ground-based FTIR and MAX-DOAS formaldehyde observations in the tropics. The observation site is Réunion Island $\left(21^{\circ} \mathrm{S}, 55^{\circ} \mathrm{E}\right)$ in the Indian Ocean. This station is part of the Network for the Detection of Atmospheric Composition Change (NDACC, http://www.ndacc.org), a network dedicated to performing high-quality long-term observations of atmospheric trace gases at globally distributed sites. The Réunion station is one of the very few NDACC stations located at southern tropical or subtropical latitudes. In preparation to a permanent installation planned for 2011, three campaigns of FTIR measurements have been performed: in October 2002, from August to October 2004, and from May to November 2007. A UV-visible Multi-Axis DOAS (MAXDOAS) instrument was operated at the same site from $\mathrm{Au}$ gust 2004 to July 2005. The inversion algorithms for both the MAX-DOAS and FTIR spectral data analyses use the Optimal Estimation Method (Rodgers, 2000) to derive information about the vertical distribution of the target gases. Since the number of independent pieces of vertical information for $\mathrm{HCHO}$ is low for both instruments, only total column results are presented and discussed in this paper. For the first time, formaldehyde columns retrieved by these two different remote sensing techniques are mutually compared. Whereas Jones et al. (2009) presented comparisons of ground-based FTIR HCHO columns with GOME data, the present paper gives the first comparisons of ground-based FTIR measurements with SCIAMACHY data. In addition, the retrievals are compared with the results of a global CTM, the IMAGESv2 model which has been recently used in an inverse modeling study of NMVOC emissions based on SCIAMACHY data (Stavrakou et al., 2009b).

We give in Sect. 2 a short summary of the Optimal Estimation Method. Sections 3 and 4 describe the FTIR and MAX-DOAS measurements and retrievals of formaldehyde, respectively, including a detailed error budget in each case. Sections 5 and 6 briefly summarize the formaldehyde measurements by SCIAMACHY and the simulations by the CTM IMAGESv2, respectively. In Sect. 7, we compare these formaldehyde data sets, accounting for the vertical sensitivity differences among the instruments by the appropriate use of averaging kernels. In Sect. 8, we discuss the main features of formaldehyde time series at Réunion Island, including the origin of the observed variabilities.

\section{Optimal Estimation Method for ground-based FTIR and MAX-DOAS retrievals}

We give in this section a brief summary of the Optimal Estimation Method (OEM) of Rodgers (2000) which is used by both FTIR and MAX-DOAS retrieval algorithms to derive $\mathrm{HCHO}$ vertical profiles (and corresponding columns) and characterize the results via the vertical information content and the error budget. Common information on FTIR and MAX-DOAS data sets is also given here.

\subsection{The retrieved state vector and a priori information}

The forward model $\boldsymbol{F}(\boldsymbol{x})$ describes how the measurement vector $\boldsymbol{y}$ depends on the state vector $\boldsymbol{x}$ :

$\boldsymbol{y}=\boldsymbol{F}(\boldsymbol{x})+\boldsymbol{\epsilon}$,

with $\epsilon$ the measurement noise. The inverse problem (find the retrieved state vector $\hat{\boldsymbol{x}}$, knowing $\boldsymbol{y}$ ) being ill-posed, the solution is constrained by an a priori state vector $\boldsymbol{x}_{a}$ and a regularization matrix $\mathbf{R}$.

The HCHO a priori profile $\boldsymbol{x}_{a}$, from the ground to $12 \mathrm{~km}$, has been constructed from data composites of the airborne experiment PEM-Tropics-B (Raper et al., 2001). We used the average formaldehyde concentration over the Southern tropical Pacific (0 to $30^{\circ} \mathrm{S} ; 160^{\circ} \mathrm{E}$ to $95^{\circ} \mathrm{W}$ ) based on the data composites available at http://acd.ucar.edu/ emmons/ DATACOMP/camp_table.htm, which is an update of the database described in Emmons et al. (2000). Between 12 and $20 \mathrm{~km}$, we have used a yearly mean of the formaldehyde profiles obtained from the IMAGESv2 model. For the upper stratosphere, the profile is based on the MIPAS-Envisat measurements (Steck et al., 2008), with a maximum of about $80 \mathrm{pptv}$ around $40 \mathrm{~km}$ at $20^{\circ} \mathrm{S}$ latitude. This a priori profile is adopted in the FTIR (in volume mixing ratio, vmr) and MAX-DOAS (in concentration) retrievals, and is shown in Fig. 1 .

In the case of OEM, the regularization matrix $\mathbf{R}=\mathbf{S}_{a}^{-1}$, with $\mathbf{S}_{a}$ the a priori covariance matrix which ideally should express the natural variability of the target gas and be evaluated from appropriate climatological data (Rodgers, 2000). However, in practice, $\mathbf{R}$ (or $\mathbf{S}_{a}$ ) is often used as a tuning parameter to obtain stable retrievals. A compromise is made also between the vertical information content and the error on the solution. The choice of the regularization matrix for FTIR and MAX-DOAS is given in the Sects. 3.2.2 and 4.2.2, respectively.

If the forward model can be considered linear, as for MAX-DOAS, $\boldsymbol{y}=\mathbf{K} \boldsymbol{x}+\boldsymbol{\epsilon}$, with $\mathbf{K}$ the weighting function matrix. The retrieved state vector is then: 

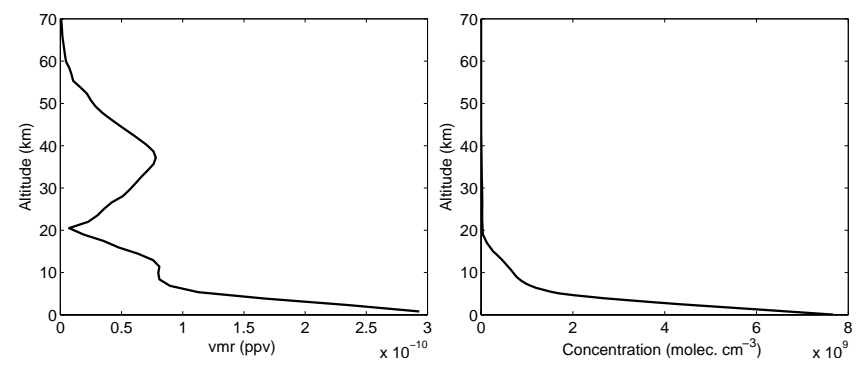

Fig. 1. Formaldehyde a priori profile used in the FTIR and MAXDOAS retrievals, in vmr (left) and concentration (right) units.

$\hat{\boldsymbol{x}}=\boldsymbol{x}_{a}+\mathbf{S}_{a} \mathbf{K}^{T}\left(\mathbf{K S}_{a} \mathbf{K}^{T}+\mathbf{S}_{\epsilon}\right)^{-1}\left(\boldsymbol{y}-\mathbf{K} \boldsymbol{x}_{a}\right)$,

where $\mathbf{S}_{\epsilon}$ is the measurement noise covariance matrix.

For FTIR measurements, the forward model is non linear and the Gauss-Newton iteration is used:

$$
\begin{aligned}
& \boldsymbol{x}_{i+1} \\
= & \boldsymbol{x}_{a}+\mathbf{S}_{a} \mathbf{K}_{i}^{T}\left(\mathbf{K}_{i} \mathbf{S}_{a} \mathbf{K}_{i}^{T}+\mathbf{S}_{\epsilon}\right)^{-1}\left(\boldsymbol{y}-\boldsymbol{F}\left(\boldsymbol{x}_{i}\right)+\mathbf{K}_{i}\left(\boldsymbol{x}_{i}-\boldsymbol{x}_{a}\right)\right) .
\end{aligned}
$$

\subsection{Characterization of the retrievals}

\subsubsection{The information content}

The vertical information content is quantified by the number of degrees of freedom for signal (DOFS), which is the trace of the so-called averaging kernel matrix $\mathbf{A}$, defined in Rodgers (2000) by:

$\mathbf{A}=\frac{\partial \hat{\boldsymbol{x}}}{\partial \boldsymbol{x}}=\left(\mathbf{K}^{T} \mathbf{S}_{\epsilon}^{-1} \mathbf{K}+\mathbf{S}_{a}^{-1}\right)^{-1} \mathbf{K}^{T} \mathbf{S}_{\epsilon}^{-1} \mathbf{K}$.

\subsubsection{Error budget}

Following the formalism of Rodgers (2000), the difference between the retrieved profile $\hat{\boldsymbol{x}}$ and the real profile $\boldsymbol{x}$ of the atmosphere can be written as:

$\hat{\boldsymbol{x}}-\boldsymbol{x}=(\mathbf{A}-\mathbf{I})\left(\boldsymbol{x}-\boldsymbol{x}_{a}\right)+\mathbf{G}_{y} \mathbf{K}_{b}\left(\boldsymbol{b}-\boldsymbol{b}_{r}\right)+\mathbf{G}_{y}\left(\boldsymbol{y}-\boldsymbol{y}_{r}\right)$,

where I the identity matrix, $\mathbf{G}_{y}$ the gain matrix representing the sensitivity of the retrieved parameters to the measurement, $\mathbf{K}_{b}$ the sensitivity matrix of the measurement state vector to the forward model parameters $\boldsymbol{b}, \boldsymbol{b}_{r}$ the estimated model parameters, and $\boldsymbol{y}_{r}$ the simulated measurement state vector after retrieval. Equation (4) splits the error in the retrieved profile into three different error sources: the smoothing error expressing the uncertainty due to the limited vertical resolution of the retrieval, the forward model parameters error, and the retrieval noise.
The smoothing error covariance $\mathbf{S}_{s}$ is calculated as:

$\mathbf{S}_{s}=(\mathbf{I}-\mathbf{A}) \mathbf{S}_{\mathrm{var}}(\mathbf{I}-\mathbf{A})^{T}$,

where $\mathbf{S}_{\mathrm{var}}$ should represent the natural variability of formaldehyde. Its diagonal elements are estimated from the average observed variability in $5^{\circ} \times 5^{\circ}$ pixels during PEMTropics-B. This variability increases from $33 \%$ at the surface up to $70 \%$ at $12 \mathrm{~km}$. Above $12 \mathrm{~km}$, we also assume a variability of $70 \%$. For the off-diagonal elements, we have chosen a Gaussian correlation with a correlation length of $4 \mathrm{~km}$, which was obtained from the IMAGESv2 model.

The forward model parameters error covariance matrix $\mathbf{S}_{f}$ is calculated according to:

$\mathbf{S}_{f}=\left(\mathbf{G}_{y} \mathbf{K}_{b}\right) \mathbf{S}_{b}\left(\mathbf{G}_{y} \mathbf{K}_{b}\right)^{T}$,

in which $\mathbf{S}_{b}$ is the covariance matrix of $\boldsymbol{b}$. For each individual model parameter, the $\mathbf{K}_{b}$ matrix is obtained by a perturbation method, while the covariance matrix $\mathbf{S}_{b}$ is an estimation of the uncertainty on the model parameter itself.

The retrieval noise covariance matrix $\mathbf{S}_{n}$ is calculated by:

$\mathbf{S}_{n}=\mathbf{G}_{y} \mathbf{S}_{\epsilon} \mathbf{G}_{y}^{T}$.

The errors on the total column $\Delta \mathrm{TC}$ are easily derived from the error covariance matrices $\mathbf{S}$ using:

$\Delta \mathrm{TC}=\boldsymbol{g}^{T} \mathbf{S g}$,

with $g$ the operator that transforms the volume mixing ratio (for FTIR) or concentration (for MAX-DOAS) profile in the corresponding total column amount.

The comparisons shown in Sect. 7 use the daily means of FTIR and MAX-DOAS total columns. The random errors on these daily means are reduced by a factor $\sqrt{n}, n$ being the number of measurements within the day. We have not divided the smoothing error (Eq. 5) by $\sqrt{n}$ because the natural variability of formaldehyde $\left(\mathbf{S}_{\mathrm{var}}\right)$ within a day was found (from the FTIR measurements) to be of the same order of magnitude as the variability from day to day. Finally, the mean total error on daily mean total columns is simply the square root of the sum of (1) the square of the total systematic error, (2) the square of the smoothing error, and (3) the sum of the square of the other random error contributions which have been divided by the number $n$ of measurements within the day.

\section{Formaldehyde from FTIR observations}

\subsection{Measurements campaigns}

A Bruker 120M Fourier transform infrared (FTIR) spectrometer has been deployed during three campaigns at Réunion Island: in October 2002, from August to October 2004, 
Table 1. Microwindows (in $\mathrm{cm}^{-1}$ ) used for the independent retrievals of $\mathrm{H}_{2} \mathrm{O}, \mathrm{HDO}, \mathrm{CH}_{4}, \mathrm{~N}_{2} \mathrm{O}$, and $\mathrm{HCHO}$. The retrieved profiles of the first four compounds are used as a priori profiles in the retrievals of $\mathrm{HCHO}$.

\begin{tabular}{lll}
\hline Target gas & Microwindows $\left(\mathrm{cm}^{-1}\right)$ & Interfering species \\
\hline $\mathrm{H}_{2} \mathrm{O}$ & $2925.10-2925.30$ & $\mathrm{CH}_{4}$ \\
& $2941.60-2941.90$ & $\mathrm{CH}_{4}, \mathrm{O}_{3}$, solar CO \\
$\mathrm{HDO}$ & $2660.00-2661.20$ & $\mathrm{CH}_{4}, \mathrm{CO}_{2}$ \\
$\mathrm{CH}_{4}$ & $2613.70-2615.40$ & $\mathrm{HDO}, \mathrm{CO}_{2}$ \\
& $2650.60-2651.30$ & $\mathrm{HDO}, \mathrm{CO}_{2}$ \\
& $2835.50-2835.80$ & $\mathrm{HDO}$ \\
& $2903.60-2904.03$ & $\mathrm{HDO}, \mathrm{H}_{2} \mathrm{O}$ \\
& $2921.00-2921.60$ & $\mathrm{HDO}, \mathrm{H}_{2} \mathrm{O}$ \\
$\mathrm{N}_{2} \mathrm{O}$ & $2806.20-2806.48$ & \\
& & \\
$\mathrm{HCHO}$ & $2763.425-2763.600$ & $\mathrm{CH}_{4}, \mathrm{HDO}, \mathrm{N}_{2} \mathrm{O}, \mathrm{O}_{3}, \mathrm{CO}_{2}$, solar $\mathrm{CO}$ \\
& $2765.725-2765.975$ & $\mathrm{CH}_{4}, \mathrm{HDO}, \mathrm{N}_{2} \mathrm{O}, \mathrm{O}_{3}, \mathrm{CO}_{2}$, solar $\mathrm{CO}$ \\
& $2778.200-2778.590$ & $\mathrm{CH}_{4}, \mathrm{HDO}, \mathrm{N}_{2} \mathrm{O}, \mathrm{O}_{3}, \mathrm{CO}_{2}$, solar $\mathrm{CO}$ \\
& $2780.800-2781.150$ & $\mathrm{CH}_{4}, \mathrm{HDO}, \mathrm{N}_{2} \mathrm{O}, \mathrm{O}_{3}, \mathrm{CO}_{2}$, solar $\mathrm{CO}$ \\
& $2810.000-2810.350$ & $\mathrm{CH}_{4}, \mathrm{HDO}, \mathrm{N}_{2} \mathrm{O}, \mathrm{O}_{3}$, solar $\mathrm{CO}^{2}$ \\
& $2855.650-2856.400$ & $\mathrm{CH}_{4}, \mathrm{HDO}, \mathrm{H}_{2} \mathrm{O}, \mathrm{O}_{3}, \mathrm{CO}_{2}$, solar $\mathrm{CO}$ \\
\hline
\end{tabular}

and from May to November 2007. For the campaigns of 2004 and 2007, the FTIR instrument was located at SaintDenis $\left(20.9^{\circ} \mathrm{S}, 55.5^{\circ} \mathrm{E}, 50 \mathrm{ma}\right.$.s.1.). It was operated in an automatic and remotely controlled way by use of BARCOS (Bruker Automation and Remote COntrol System) developed at BIRA-IASB (Neefs et al., 2007). More detailed specifications of the 2002 and 2004 experiments are given in Senten et al. (2008); the 2007 experiment was conducted in an almost identical way. In the present work, we will not include results from the first campaign in 2002, because (i) it represents only one month of data, and (ii) no MAX-DOAS or SCIAMACHY data are available for that year.

The FTIR solar absorption measurements are performed in a wide spectral range (around $600-4500 \mathrm{~cm}^{-1}$ ), which allow the retrieval of many species (Senten et al., 2008). The formaldehyde spectra are recorded in the $2400-3310 \mathrm{~cm}^{-1}$ domain. At low solar zenith angles (SZA), the spectral resolution is $0.00513 \mathrm{~cm}^{-1}$ with an optical path difference of $175.4 \mathrm{~cm}$, and 5 scans are co-added. At higher SZA, the spectral resolution is reduced to $0.00893 \mathrm{~cm}^{-1}$, and the number of co-added scans to 3 . The switch between high to low resolution occurs when the airmass factor changes by more than $7 \%$ during the time needed to record the spectra; this occurs around $60^{\circ}$ SZA. By reducing the resolution and the number of scans, we effectively shorten the recording time of the spectra.

The volume mixing ratio profiles of target gases are retrieved from the shapes of their absorption lines, which are pressure and temperature dependent. Daily pressure and temperature profiles have been taken from the National Centers for Environmental Prediction (NCEP). The observed absorp- tion line shapes also depend on the instrument line shape (ILS) which is therefore included in the forward model of the retrieval code. In order to know the ILS and at the same time to monitor the alignment of the instrument, a reference low-pressure $(2 \mathrm{hPa}) \mathrm{HBr}$ cell spectrum was recorded at local noon with the sun as light source, whenever the meteorological conditions permitted so. The software LINEFIT is used for the analysis of the cell sprectra, as described in Hase et al. (1999). In this approach, the complex modulation efficiencies are described by 40 parameters ( 20 for amplitude and 20 for phase orientation) at equidistant optical path differences.

\subsection{FTIR retrieval strategy}

\subsubsection{Choice of microwindows and spectroscopic databases}

The FTIR retrievals are performed using the algorithm SFIT2 (Rinsland et al., 1998), version 3.92, jointly developed at the NASA Langley Research Center, the National Center for Atmospheric Research (NCAR) and the National Institute of Water and Atmosphere Research (NIWA). The measurement state vector $\boldsymbol{y}$ of Eq. 2 consists of one or more narrow spectral intervals (microwindows) selected in the solar absorption FTIR spectrum. The retrieved state vector $\hat{\boldsymbol{x}}$ contains the volume mixing ratio vertical profile of the target gas discretized in a vertical grid (here, 66 equidistant levels from the ground to $100 \mathrm{~km}$ ), the total columns of interfering gases and a few fitted parameters (wavenumber scale multipliers, background curve,...). 
The choice of microwindows is critical for a species like formaldehyde which has very weak absorptions in the infrared. In particular, it is important to minimize the impact of interfering species absorbing in the same spectral region.

Table 1 gives the list of microwindows used in this work. The selection of microwindows is not trivial at the location of Saint-Denis because there is a considerable amount of water vapour. We therefore have to avoid as much as possible interferences with water vapour lines. The microwindows with the strongest HCHO signal are the ones at 2778 and $2780 \mathrm{~cm}^{-1}$, already used in Notholt et al. (1997) and Jones et al. (2009). The two first microwindows at 2763 and $2765 \mathrm{~cm}^{-1}$ were chosen for their relatively small absorptions from interfering species. These four microwindows (2763, 2765,2778 and $2780 \mathrm{~cm}^{-1}$ ) are part of the microwindows set for HCHO advised by Meier et al. (2004). The $2810 \mathrm{~cm}^{-1}$ microwindow was indicated by the LINEFINDING tool of Notholt et al. (2006), together with the 2778 and $2780 \mathrm{~cm}^{-1}$ ones. Other microwindows indicated by LINEFINDING with even larger priority than the $2810 \mathrm{~cm}^{-1}$ one have been discarded because, either they contain too strong HDO or $\mathrm{H}_{2} \mathrm{O}$ lines, or they contain some spectroscopic features that were badly fitted in the retrieval. The last microwindow at $2855 \mathrm{~cm}^{-1}$ is added to get additional information on the HDO and solar absorptions, and so to reduce the correlation between the HDO and solar signals and the $\mathrm{HCHO}$ one in the other microwindows.

The profiles of the interfering species $\mathrm{H}_{2} \mathrm{O}, \mathrm{HDO}, \mathrm{CH}_{4}$, and $\mathrm{N}_{2} \mathrm{O}$ were retrieved beforehand and independently in the microwindows listed in Table 1 . The daily means of the $\mathrm{H}_{2} \mathrm{O}$ and $\mathrm{HDO}$ retrieved profiles were used as daily a priori profiles in the retrievals of $\mathrm{CH}_{4}$, and scaled using a single parameter for each species. Finally, the daily means of the retrieved profiles of the four molecules $\left(\mathrm{H}_{2} \mathrm{O}, \mathrm{HDO}\right.$, $\mathrm{CH}_{4}$, and $\mathrm{N}_{2} \mathrm{O}$ ) are used as daily a priori profiles in the retrievals of $\mathrm{HCHO}$. For the interfering species having a small impact on the HCHO retrievals, a single a priori profile is used for all spectra. So for $\mathrm{O}_{3}$, we have used the 5years (1985-1989) climatology from UGAMP (http://badc. nerc.ac.uk/data/ugamp-o3-climatology) above Réunion Island. For the $\mathrm{CO}$ solar lines, we used the empirical lineby-line model of Hase et al. (2006). In the formaldehyde retrieval process, the a priori profile of each of the interfering species is scaled using a single parameter.

We have used, for all species except HCHO, the HITRAN 2004 spectroscopic line parameters (Rothman et al., 2005), with the additional official updates published on the HITRAN web-site (http://www.cfa.harvard.edu/hitran/). For formaldehyde, we have used the very recent linelist of Perrin et al. (2009).

\subsubsection{Choice of the regularization matrix}

We have chosen to use Tikhonov L1 regularization (Tikhonov, 1963), i.e., the constraint matrix is defined as
$\mathbf{R}=\alpha \mathbf{L}_{1}^{T} \mathbf{L}_{1}$, with $\alpha$ the regularization strength and $\mathbf{L}_{1}$ the first derivative operator:

$$
\mathbf{L}_{\mathbf{1}}=\left(\begin{array}{ccccc}
-1 & 1 & 0 & \ldots & 0 \\
0 & -1 & 1 & \vdots & \vdots \\
\vdots & \ddots & \ddots & \ddots & 0 \\
0 & \ldots & 0 & -1 & 1
\end{array}\right)
$$

In this approach, the difference between the retrieved profile and the a priori profile is constrained to be a constant profile. This regularization avoids the appearance of spurious oscillations in the retrieved formaldehyde profiles that occurred in the usual OEM implementation. This approach was adopted recently for $\mathrm{H}_{2} \mathrm{O}$ (Sussmann et al., 2009) and, within an European FTIR network (project HYMN, http: //www.knmi.nl/samenw/hymn/), for $\mathrm{CH}_{4}$.

For the determination of $\alpha$, we have followed the method illustrated in Fig. 1 of Steck (2002) which shows that the obtained DOFS is determined by the value of $\alpha$. Initial trials with the usual OEM approach indicated that the DOFS that can reasonably be achieved for our HCHO retrievals is about 1.1 , implying a value of $\alpha=55$.

\subsection{Characterization of the FTIR retrievals}

\subsubsection{Vertical information content}

As mentioned previously, the vertical information contained in the FTIR retrievals can be characterized by the averaging kernel matrix A (Eq. 3) and its trace (DOFS). This matrix depends on measurement and retrieval parameters including the solar zenith angle, the spectral resolution and signal to noise ratio, the choice of spectral microwindows, the regularization matrix, ... We obtain a mean DOFS of 1.1 and its standard deviation $(1 \sigma)$ for all measurements at different solar zenith angles is 0.1. The rows of $\mathbf{A}$ are the so-called averaging kernels and they represent the sensitivity of the retrieved profile to the real profile. We give in Fig. 2a the mean of the averaging kernels obtained in the formaldehyde retrievals. As expected with the DOFS close to one, we can see that the averaging kernels are not vertically resolved. They all peak at about the same altitude $(\simeq 10 \mathrm{~km})$. The retrieved profile is sensitive only to a change in the true profile that occurs between the ground and about $20 \mathrm{~km}$, with a maximum of sensitivity around $10 \mathrm{~km}$. It is useful to note that such a change between 0 and $20 \mathrm{~km}$ will also impact the retrieved profile above $20 \mathrm{~km}$ where we do not have sensitivity. This is due to the Tikhonov approach where the retrieved profile is constrained to the shape of the a priori profile (see Sect. 3.2.2). However, the HCHO column above $20 \mathrm{~km}$ represents only about $1.5 \%$ of the total column, and this effect is therefore negligible. 
Table 2. FTIR and MAX-DOAS error budget (in \%) on formaldehyde individual total columns, and on the daily mean total columns used for the comparisons in Sect. 7.

\begin{tabular}{lllll}
\hline & FTIR & \multicolumn{3}{l}{ MAX-DOAS } \\
\hline Errors & $\begin{array}{l}\text { Individual } \\
{[\%]}\end{array}$ & $\begin{array}{l}\text { Daily mean } \\
{[\%]}\end{array}$ & $\begin{array}{l}\text { Individual } \\
{[\%]}\end{array}$ & $\begin{array}{l}\text { Daily mean } \\
{[\%]}\end{array}$ \\
\hline Smoothing & 14 & 14 & 20 & 20 \\
Retrieval noise & 7 & 5 & 9 & 1.5 \\
Model parameters & 10 & 7 & 12 & 2 \\
Total random error & 18 & 16 & 25 & 20 \\
Total systematic error & 8 & 8 & 9 & 9 \\
Total error & 20 & 18 & 27 & 22 \\
\hline
\end{tabular}

\subsubsection{FTIR error budget}

The model parameters giving rise to a systematic error on the retrieved formaldehyde are the spectroscopic parameters: the line intensities and the pressure broadening coefficients of the absorption lines present in our microwindows. The uncertainties on the line intensities are between 7 and $10 \%$ for the strong and medium lines used in this work (Perrin et al., 2009). We use 10\%, to be considered as an upper limit. The values for the air-broadening coefficients have not been updated since the work of Tejwani and Yeung (1977), who did not provide uncertainties. We therefore use a $10 \%$ uncertainty. The errors on HCHO total column due to uncertainties on line intensities and on air-broadening coefficients are then (Eqs. 6 and 8) 5\% and 7\%, respectively. The total systematic error is the quadrature sum of these two errors: $8 \%$.

The smoothing error has been discussed in Sect. 2.2.2.

The largest contributions to the model parameters random error on the formaldehyde total columns are due to the temperature uncertainty and the interfering species, in particular HDO. For temperature, which influences formaldehyde retrievals via the temperature dependence of the absorption lines, the $\mathbf{S}_{b}$ matrix was estimated using the differences between the NCEP and ECMWF temperature profiles calculated for Réunion Island in the period August to October 2004, as explained in more details in Senten et al. (2008). For each of the main interfering species (HDO, $\mathrm{H}_{2} \mathrm{O}$, and $\mathrm{CH}_{4}$ ), the $\mathbf{S}_{b}$ matrix was estimated from the error budget on their prior retrievals. We also considered the contributions to the random error on the formaldehyde total columns due to uncertainties in the solar zenith angle, the wavenumber shift, the baseline, and the ILS parameters. Only the ILS parameters uncertainties lead to a significant error on the total columns. In their case, the $\mathbf{S}_{b}$ matrix was estimated using the differences between the parameters obtained with LINEFIT (see Sect. 3.1) for two adjacent days of cell measure- ments. The random errors on $\mathrm{HCHO}$ total column due to uncertainties on temperature, interfering species and ILS are then (Eqs. 6 and 8) 7\%, 6\% and 3\%, respectively. The total model parameters error is then $10 \%$.

The random error due to the measurement noise is calculated from Eq. (7), where $\mathbf{S}_{\epsilon}$ is assumed to be diagonal, with the square of the spectral noise as diagonal elements. The spectral noise within the selected microwindows is determined as the root mean squared (rms) value of the differences between the observed and calculated spectrum.

Table 2 summarizes the significant contributions to the random and systematic error budget on the formaldehyde individual and daily mean (see Sect. 2.2.2) total columns. The number of FTIR measurements within a day varies from 1 to 20 , but with a median value of only 2 .

\section{Formaldehyde from MAX-DOAS observations}

\subsection{Instrumental set-up and DOAS analysis}

The IASB-BIRA MAX-DOAS instrument operated at Réunion Island is described in detail in Theys et al. (2007). It consists of a grating spectrometer installed inside a thermoregulated protection case and connected to an entrance telescope through a fiber optic bundle. The telescope itself is connected to a rotating mirror allowing viewing elevation angles to be scanned from $3^{\circ}$ above the horizon up to zenith $\left(90^{\circ}\right.$ elevation angle). The spectrometer is mounted with a ruled grating of 600 grooves $/ \mathrm{mm}$ covering a spectral range from 300 to $450 \mathrm{~nm}$. It is equipped with a $1340 \times 400$ backilluminated $\mathrm{CCD}$ detector cooled to $-40^{\circ} \mathrm{C}$ using a triple stage Pelletier system. Spectrometer resolution and sampling ratio are $0.75 \mathrm{~nm}$ FWHM and 7 pixels/FWHM, respectively. The MAX-DOAS instrument was operated on the roof of the LACy (Laboratoire de l'Atmosphère et des Cyclones) of the 


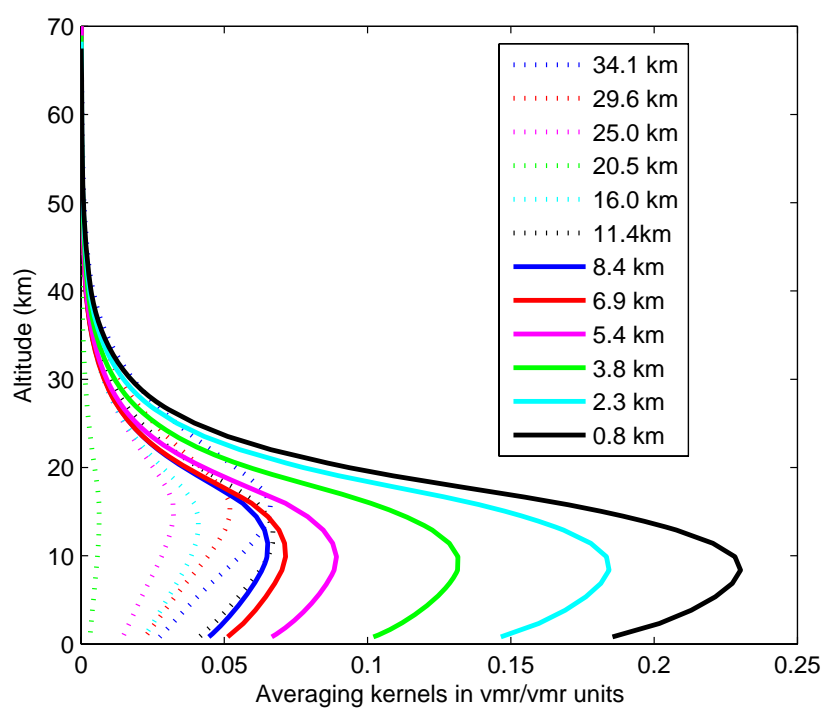

(a) FTIR

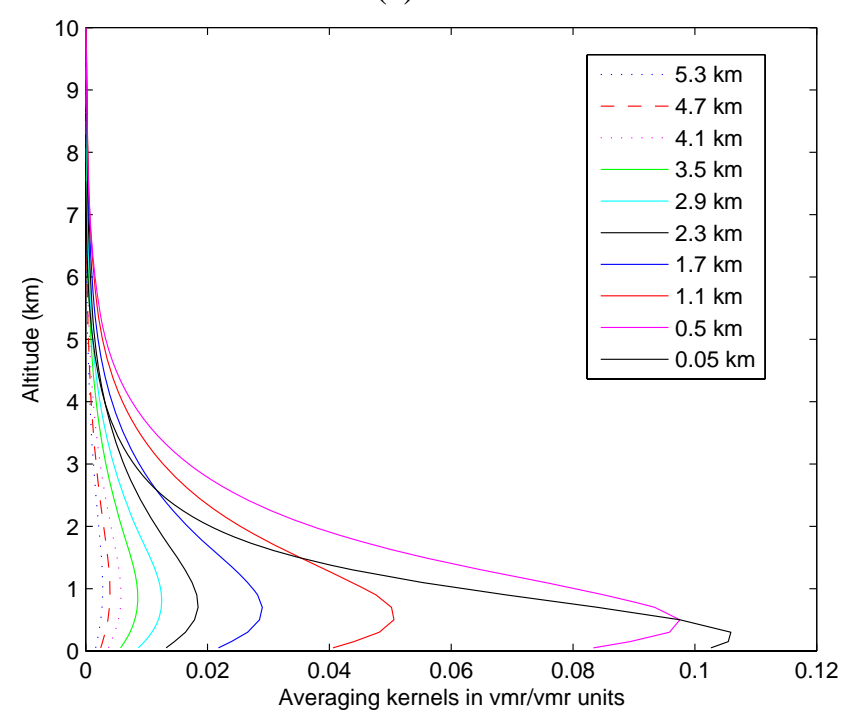

(b) MAX-DOAS

Fig. 2. FTIR (a) and MAX-DOAS (b) averaging kernels (ppv/ppv). Note that the scale of (a) and (b) is not the same.

University of Saint-Denis from August 2004 to July 2005. It pointed towards the sea (North direction) at the following elevation angles above the horizon: $3^{\circ}, 6^{\circ}, 10^{\circ}, 18^{\circ}$, and zenith. A complete scan required approximately $15 \mathrm{~min}$.

Measured zenith and off-axis radiance spectra are analyzed using the DOAS technique (Platt and Stutz, 2008). Formaldehyde differential slant column densities (DSCDs), which are the direct product of the DOAS analysis, are retrieved in the 336-358 $\mathrm{nm}$ wavelength range, taking into account the spectral signature of $\mathrm{O}_{3}, \mathrm{NO}_{2}, \mathrm{BrO}$, the collision

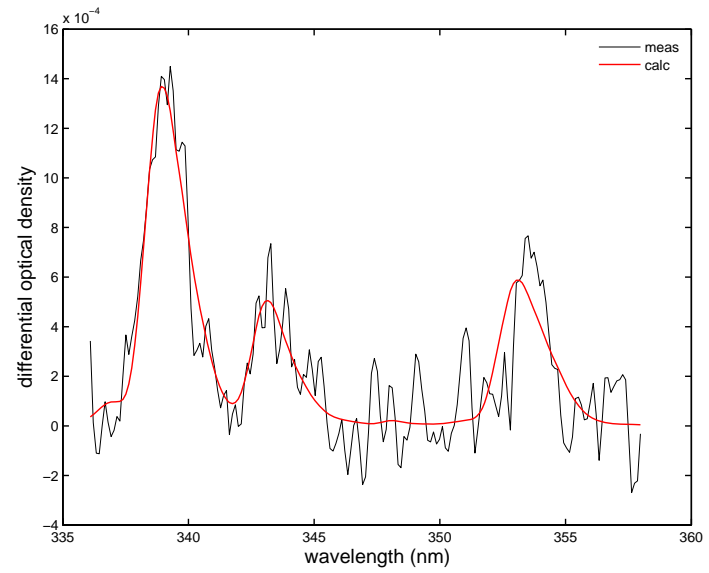

Fig. 3. Example of a HCHO DOAS fit at Réunion Island.

pair of oxygen molecules $\mathrm{O}_{4}$, and the Ring effect. The crosssections used in the DOAS fit are taken from the following sources: Meller and Moortgat (2000) for HCHO (293 K), Bogumil et al. (2003) for $\mathrm{O}_{3}$ ( $223 \mathrm{~K}$ and $243 \mathrm{~K}$ ), Vandaele et al. (1997) for $\mathrm{NO}_{2}(220 \mathrm{~K})$, Wilmouth et al. (1999) for $\mathrm{BrO}$ (228 K), and Greenblatt et al. (1990) for $\mathrm{O}_{4}$. To correct for the Ring effect (Grainger and Ring, 1962), a pseudo absorption cross section generated from Vountas et al. (1998) using the SCIATRAN radiative transfer model (Rozanov et al., 2001) is included in the fit. Similar settings are used for the retrieval of $\mathrm{O}_{4}$ slant columns except for the fitting interval, which is slightly shifted towards longer wavelengths (338.5$364.5 \mathrm{~nm}$ ) in order to capture the strong $\mathrm{O}_{4}$ absorption band centered at $360 \mathrm{~nm}$.

An example of a DOAS fit for HCHO is shown in Fig. 3. The typical residual RMS is about $5 \times 10^{-4}$ and the detection limit is about $7 \times 10^{15} \mathrm{molec} / \mathrm{cm}^{2}$ in slant column.

\subsection{MAX-DOAS retrieval strategy}

\subsubsection{Profiling algorithm}

The IASB-BIRA profiling algorithm, designed to retrieve vertical distributions of $\mathrm{BrO}$ and $\mathrm{NO}_{2}$ from zenith-sky DOAS observations (Hendrick et al., 2004, 2007), has been adapted to the retrieval of HCHO profiles from MAX-DOAS measurements. Since HCHO is an optically thin absorber, the OEM for the linear case (Eq. 1) can be considered. The retrieved state vector is a vertical profile of trace gas concentration and the measurement vector $\boldsymbol{y}$ is a set of HCHO DSCDs corresponding to one scan and analyzed relative to the zenith reference from the same scan. They are a function of the solar zenith angle (SZA), the relative azimuth angle $\varphi$ between the sun and the viewing direction, and the elevation angle $\theta$. The weighting function matrix $\mathbf{K}$ therefore also depends on SZA, $\varphi$, and $\theta$. One should note that, in the DOAS 
community, the weighting functions are also referred to as box air mass factors (Wagner et al., 2007).

The forward model consists of the radiative transfer model (RTM) UVspec/DISORT (Mayer and Kylling, 2005). This model is based on the discrete ordinate method and includes a treatment of multiple scattering in the pseudo-spherical geometry approximation. It has been validated through several intercomparison exercises (Hendrick et al., 2006; Wagner et al., 2007). Pressure and temperature profiles are taken from NCEP and the ozone profile is from the AFGL reference atmosphere for the tropics (Anderson et al., 1986). The altitude grid is as follows: $0,0.1,0.2$ to $10 \mathrm{~km}$ in steps of $0.2 \mathrm{~km}, 12$ to $20 \mathrm{~km}$ in steps of $2 \mathrm{~km}$, and 25 to $90 \mathrm{~km}$ in steps of $5 \mathrm{~km}$. The wavelength is fixed to $339 \mathrm{~nm}$ and the surface albedo (lambertian reflector) to 0.08 (annual mean for $20.9^{\circ} \mathrm{S}$ and $55.5^{\circ} \mathrm{E}$, given by the Koelemeijer et al. (2003) climatology).

\subsubsection{Choice of the regularization matrix}

The $\mathbf{S}_{\epsilon}$ matrix being fixed, the a priori covariance matrix $\mathbf{S}_{a}$ can act as a tuning parameter (Schofield et al., 2004) and diagonal elements corresponding to an error of $70 \%$ have been empirically determined in order to ensure a good fit of the measurements. $\mathbf{S}_{a}$ also contains off-diagonal elements accounting for correlations between $\mathrm{HCHO}$ values at different altitude levels. These terms have been added as Gaussian functions using a correlation length of $400 \mathrm{~m}$ (Hendrick et al., 2004).

\subsubsection{Aerosol extinction profiles}

Since the light path of the different off-axis directions is strongly dependent on aerosols, a good estimate of the aerosol extinction profile is required to calculate accurate $\mathrm{HCHO}$ weighting functions for vertical profile retrieval. For this purpose, we have used MAX-DOAS measurements of the oxygen collision complex $\mathrm{O}_{4}$ similarly to Heckel et al. (2005). The principle is the following: since the $\mathrm{O}_{4}$ profile is well-known and nearly constant (it varies with the square of the $\mathrm{O}_{2}$ monomer), the observed $\mathrm{O}_{4}$ absorption depends on the atmospheric distribution of photon paths. Therefore, any change in the light path distribution due to aerosols has an impact on $\mathrm{O}_{4}$ MAX-DOAS measurements (Wagner et al., 2004; Frieß et al., 2006). In order to prevent any complication in the radiative transfer due to the presence of clouds, aerosol extinction profiles (and therefore $\mathrm{HCHO}$ profiles) are retrieved only for clear-sky days. The selection of clear-sky days is based on the shape and smoothness of the $\mathrm{O}_{4}$ DSCD diurnal variation (Wagner et al., 2004; Theys et al., 2007). Morning and afternoon are treated separately in order to also include days with only clear-sky morning or afternoon.

Ideally, an aerosol extinction profile should be retrieved at each MAX-DOAS scan since the aerosol loading can vary during the day. However, using the RTM UVspec/DISORT,

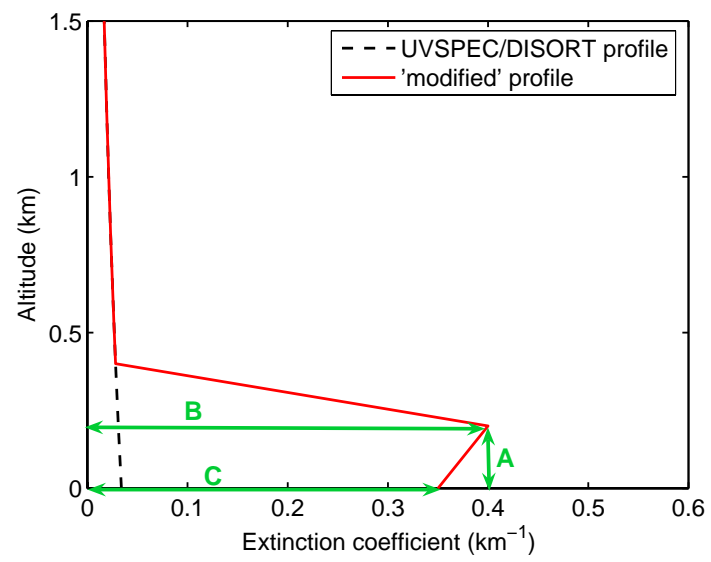

Fig. 4. Extinction profile given by the aerosol model of Shettle (1989) included in UVspec/DISORT and corresponding to oceanic conditions with a visibility of $100 \mathrm{~km}$ (black dashed line), and example of a "perturbed" extinction profile (red solid line) corresponding to values of parameters A, B, C equal to $0.2 \mathrm{~km}, 0.4 \mathrm{~km}^{-1}$, and $0.35 \mathrm{~km}^{-1}$.

this would require unrealistically large computing time. Therefore, we derive a mean aerosol profile for each selected clear-sky morning or afternoon using a look-up table (LUT) approach like in Irie et al. (2008). In our approach, a LUT of $\mathrm{O}_{4}$ airmass factors $\left(\mathrm{AMF}_{\mathrm{O} 4}\right)$ is created for a large number of different aerosol extinction profiles and viewing geometries employing the RTM UVspec/DISORT. The different aerosol extinction profiles are generated by applying a perturbation to the extinction profile given by the aerosol model of Shettle (1989) included in UVspec/DISORT and corresponding to oceanic conditions with a visibility of $100 \mathrm{~km}$ (see Fig. 4). This perturbation depends on three parameters: its altitude (A), the extinction coefficient at altitude A (B) and at the ground $(\mathrm{C})$. $\mathrm{A}, \mathrm{B}$, and $\mathrm{C}$ were varied in the following ranges: $0,0.1,0.2$ to $1.2 \mathrm{~km}$ in steps of $0.2 \mathrm{~km}(\mathrm{~A}), 0.1$ to $0.9 \mathrm{~km}^{-1}$ in steps of $0.1 \mathrm{~km}^{-1}$ (B), and 0.05 to $0.95 \mathrm{~km}^{-1}$ in steps of $0.1 \mathrm{~km}^{-1}(\mathrm{C})$. This means that 800 aerosol extinction profiles and corresponding $\mathrm{AMF}_{\mathrm{O} 4}$ sets have been generated.

In practice, for a given morning or afternoon, we proceed as follows to determine the "mean" aerosol extinction profile: for each aerosol extinction profile, the $\mathrm{AMF}_{\mathrm{O} 4}$ are interpolated to the SZA, $\varphi$, and $\theta$ corresponding to the different offaxis directions of the measured $\mathrm{O}_{4}$ DSCDs. The $\mathrm{O}_{4}$ DSCDs are then plotted as a function of the interpolated $\mathrm{AMF}_{\mathrm{O} 4}$ (the so-called Langley-plot) and the aerosol extinction profile corresponding to the set of $\mathrm{AMF}_{\mathrm{O} 4}$ that gives the most linear Langley-plot is considered as a good proxy of the true extinction profile (a Langley-plot with good linearity means that the same $\mathrm{O}_{4}$ vertical column is obtained for all viewing directions). The objective criterion used for determining the linearity of the Langley-plot is the RMS of the linear fit applied to the data. For each clear-sky morning or afternoon, the selected aerosol extinction profile is the one corresponding to 

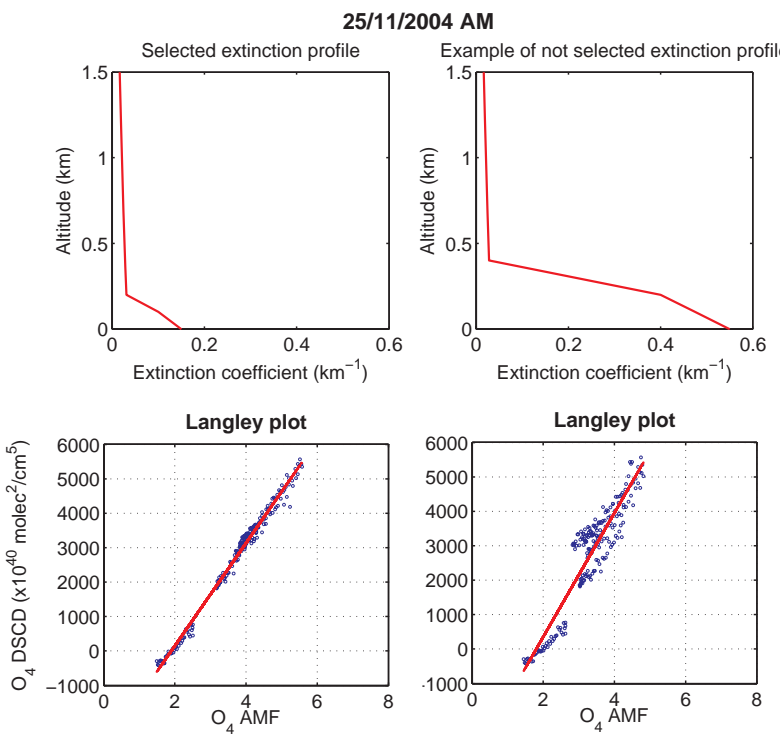

Fig. 5. Example of aerosol extinction profile selection (25 November 2004 morning) based on $\mathrm{O}_{4}$ Langley-plot. The selected extinction profile and corresponding Langley-plot appear on the lefthand side while an example of a not selected extinction profile and corresponding Langley-plot is presented on the righthand side. The RMS of the linear fit is $166 \times 10^{40} \mathrm{~mol}^{2} / \mathrm{cm}^{5}$ for the selected aerosol extinction profile (left) and $813 \times 10^{40} \mathrm{~mol}^{2} / \mathrm{cm}^{5}$ for the other one (right).

the set of $\mathrm{AMF}_{\mathrm{O} 4}$ giving the lowest RMS below a threshold value of $300 \times 10^{40} \mathrm{~mol}^{2} / \mathrm{cm}^{5}$. If this threshold value is not reached, the corresponding clear-sky morning or afternoon is not taken into account in the study. An example of an aerosol extinction profile selection is presented in Fig. 5.

Using this RMS-based criterion, aerosol extinction profiles are selected for 52 mornings and 42 afternoons, and all together, only 6 different profiles are found (see Fig. 6) and used to calculate appropriate sets of $\mathrm{HCHO}$ weighting functions.

\subsection{Characterization of the MAX-DOAS retrievals}

\subsubsection{Retrieval fit results}

The HCHO profile retrievals are quality-checked by examining the retrieval fit results, which are the comparison between the measured HCHO DSCDs and those calculated using the retrieved profiles. Figure 7 shows examples of retrieval fit results obtained on 25 November 2004 morning for some MAX-DOAS scans between $58^{\circ}$ and $68^{\circ}$ SZA. A similarly good agreement is found between measured and calculated HCHO DSCDs for all selected mornings and evenings, meaning that the settings used for the $\mathrm{HCHO}$ weighting function calculations, especially the aerosol extinction profiles, are good estimates of the real atmospheric conditions.

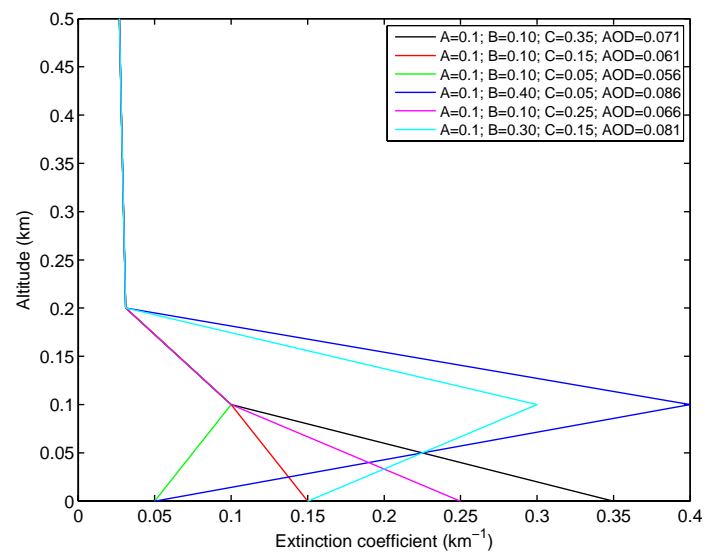

Fig. 6. Different aerosol extinction profiles selected for the clearsky days during the August 2004-July 2005 period at Réunion Island. Parameters $\mathrm{A}, \mathrm{B}$, and $\mathrm{C}$ are in $\mathrm{km}, \mathrm{km}^{-1}$ and $\mathrm{km}^{-1}$, respectively. The AOD corresponding to each extinction profile is also given.
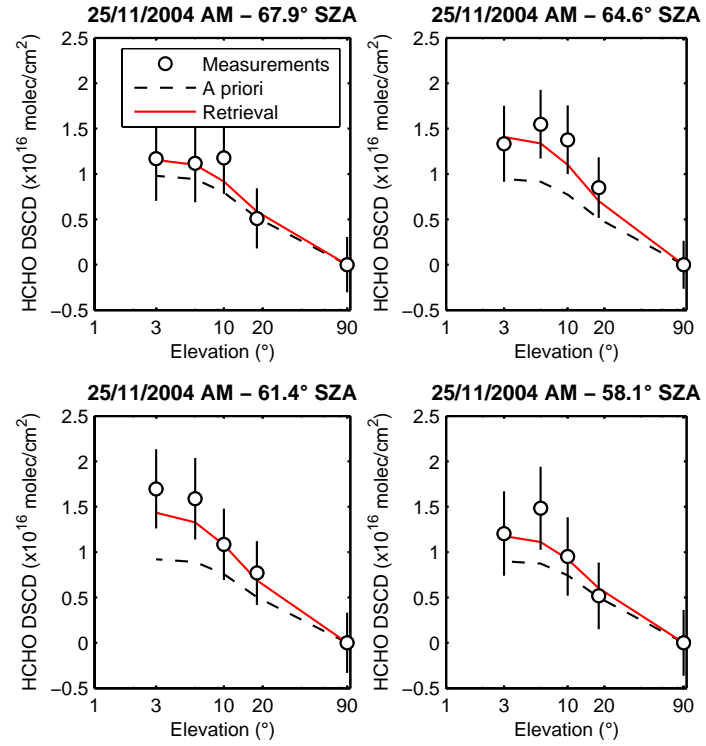

Fig. 7. Examples of retrieval fit results obtained on 25 November 2004 morning for some MAX-DOAS scans between $58^{\circ}$ and $68^{\circ}$ SZA.

\subsubsection{Vertical information content}

A typical example of $\mathrm{HCHO}$ averaging kernels is presented in Fig. 2b. We see that, according to the MAX-DOAS geometry, most of the information on the vertical distribution of HCHO contained in the measurements is located below $2.5 \mathrm{~km}$ of altitude. The trace of $\mathbf{A}$ (DOFS) is $0.7 \pm 0.1$ on average for a scan. This rather low DOFS value is mainly due to the relatively poor signal to noise ratio of the measurements performed in this campaign and to the small number of elevation angles (5 with zenith) available 
Table 3. MAX-DOAS forward model parameters $b$, their uncertainty, and the corresponding forward model parameters errors. $2.5 \mathrm{~K}$ is the annual variability of the NCEP temperature at $1000 \mathrm{hPa}$. 0.03 is the annual variability of the surface albedo at $20.9^{\circ} \mathrm{S}$, $55.5^{\circ} \mathrm{E}$ (Koelemeijer et al., 2003). For ozone, a variability of $10 \%$ has been arbitrarily chosen. Regarding the aerosols, the variability in the AOD (Aerosol Optical Depth) estimated from the aerosol profiles shown in Fig. 6 is 0.1 . The total forward model parameters error is calculated by adding in quadrature the different error sources.

\begin{tabular}{lll}
\hline Parameter $b$ & $\begin{array}{l}\text { Uncertainty } \\
\text { on } b\end{array}$ & $\begin{array}{l}\text { Error on HCHO } \\
\text { total column }(\%)\end{array}$ \\
\hline Temperature & $\pm 2.5 \mathrm{~K}$ & $<1$ \\
Albedo & \pm 0.03 & 1 \\
Aerosols & \pm 0.1 & 12 \\
Ozone & $\pm 10 \%$ & $<1$ \\
Total & & 12.1 \\
\hline
\end{tabular}

for each scan. A sensitivity analysis indicates that a DOFS of up to 1.6 could be achieved by reducing the noise on HCHO SCDs $\left(0.45 \times 10^{16} \mathrm{~mol} / \mathrm{cm}^{2}\right.$ for this campaign $)$ down to $0.15 \times 10^{16} \mathrm{~mol} / \mathrm{cm}^{2}$ as for our most recent instrument operating in Beijing, and by considering four additional elevation angles $\left(2,8,15\right.$, and $\left.30^{\circ}\right)$. However, most of this DOFS increase is due to the noise reduction on HCHO SCDs and not so much to the increase of the number of viewing angles, because measurements at different elevation angles are not completely independent.

\subsubsection{MAX-DOAS error budget}

The main source of systematic error is the uncertainty on the $\mathrm{HCHO}$ cross-sections. This uncertainty is estimated to be $9 \%$, which is the mean difference between the Cantrell et al. (1990) and Meller and Moortgat (2000) HCHO cross sections.

The smoothing error, the forward model parameters error, and the measurement noise error are calculated according to Eqs. (5-7), respectively. The measurement covariance matrix $\mathbf{S}_{\epsilon}$ is taken diagonal, with the square of the statistical errors on the HCHO DOAS fit as its diagonal elements. This results from the fact that in most cases, the residuals from the DOAS fit are found to be dominated by the random noise of the detectors. The forward model parameters $b$ for which we calculate $\mathbf{K}_{b}$ for the MAX-DOAS retrievals, and their associated uncertainties $\mathbf{S}_{b}$ are listed in Table 3.

The MAX-DOAS error budget on individual and daily mean HCHO total column is summarized in Table 2. The random error on the daily mean is significantly lower because the number of MAX-DOAS measurements within a day varies from 4 to 84 , with a median value of 36 .

\section{Formaldehyde from SCIAMACHY observations}

Global tropospheric HCHO columns have been retrieved from the SCIAMACHY UV-Visible nadir spectrometer onboard ENVISAT (launched in 2001), using the differential optical absorption spectroscopy (DOAS) technique (Platt and Stutz, 2008). The HCHO retrievals used in the present paper are described in detail in De Smedt et al. (2008). Therefore, we only give a very brief summary of the retrieval characteristics here.

Slant columns are fitted in the 328.5-346 nm wavelength range using the WINDOAS analysis software (Van Roozendael et al., 1999). This choice of the fitting interval minimizes uncertainties due to a polarization anomaly affecting the SCIAMACHY spectra around $350 \mathrm{~nm}$, and to a major absorption band of the $\mathrm{O}_{4}$ collision complex (centered near $360 \mathrm{~nm}$ ). Furthermore, it decreases fitting residuals in tropical areas and reduces noise over the oceans (De Smedt et al., 2008). Vertical columns are obtained by dividing the slant columns by air mass factors (AMFs) (Palmer et al., 2001) calculated using scattering weights evaluated from radiative transfer calculations performed with the DISORT code (Mayer and Kylling, 2005). A correction for cloud effects is applied based on the independent pixel approximation (Martin et al., 2002). The ground albedo is obtained from the climatology of Koelemeijer et al. (2003). Cloud information is provided by the FRESCO v5 algorithm (Koelemeijer et al., 2002; Wang et al., 2008). For the determination of the AMFs, $\mathrm{HCHO}$ vertical profiles are needed a priori (Palmer et al., 2001): they are provided by the IMAGESv2 global chemistry transport model (Stavrakou et al., 2009a) on a daily basis and interpolated for each satellite geolocation.

A random and a systematic error component of the slant columns is estimated (De Smedt et al., 2008). For a single pixel, the random error reaches $10^{16} \mathrm{~mol} / \mathrm{cm}^{2}$. However, when considering regionally and temporally averaged columns, this error is reduced by the square root of the number of observations included in the mean. The error on the air mass factors is mainly due to uncertainties on the cloud properties and on the HCHO vertical distribution. On average, the total uncertainty on the monthly $\mathrm{HCHO}$ vertical column ranges between 20 and $40 \%$ for regions with high $\mathrm{HCHO}$ signal to noise ratio (De Smedt et al., 2008). Furthermore, no correction has been explicitly applied to account for the effect of aerosols on the air mass factors. The effect of nonabsorbing aerosols is implicitly included through the cloud correction (Boersma et al., 2004), and results in a relatively small error (generally lower than 16\%) on the air mass factor calculation. Absorbing aerosols can lead to a reduction of the air mass factor by up to $40 \%$ (Fu et al., 2007). The omission of the aerosol correction may thus lead to a significant underestimation of the derived $\mathrm{HCHO}$ column by up to $40 \%$ over fire scenes. The inclusion of an explicit aerosol correction in the retrieval algorithm will be addressed in future work. 
In this study, daily averaged $\mathrm{HCHO}$ columns have been calculated in a region of $500 \mathrm{~km}$ around Saint-Denis, using observations with a cloud fraction below 0.4. Only days for which at least 20 SCIAMACHY pixels were available and for which the total error was smaller than $2.5 \times 10^{15} \mathrm{~mol} / \mathrm{cm}^{2}$ have been selected. In 2004, the mean total error on the daily averaged columns is $40 \%$, divided into $15 \%$ of random errors and $37 \%$ of systematic errors. The mean number of satellite observations per day is 200 . In 2007, total errors are larger. There are two reasons for this. First, the degradation of the satellite with years increases the fitting residuals. This impacts the random error. Second, the observed cloud fractions are larger, which increases the AMF uncertainties and reduces the number of pixels included in the daily means. The mean total error is $60 \%$ (30\% random and $51 \%$ systematic) and the averaged number of observations is only 100 .

\section{Formaldehyde from the CTM IMAGESv2}

The global IMAGESv2 chemistry-transport model (CTM) is an updated version of the IMAGES model (Müller and Brasseur, 1995; Müller and Stavrakou, 2005). It calculates the daily mean concentrations of 80 trace gases at a horizontal resolution of $4 \times 5$ degrees and 40 vertical levels extending from the surface up to the top of the troposphere. Monthly mean ECMWF wind fields are used to drive advection of chemical compounds, whereas boundary layer diffusion, deep convection and other cloud processes are parameterized using daily ECMWF fields. The NMVOC chemical mechanism of the model has been revised on the basis of box model calculations with the quasi-explicit Master Chemical Mechanism (MCM, Saunders et al., 2003) in order to provide a more reliable representation of the formaldehyde produced by pyrogenic and biogenic hydrocarbon emissions (Stavrakou et al., 2009a). The model time step is equal to one day. Diurnal cycle simulations with a time step of $20 \mathrm{~min}$ are performed to derive correction factors for the kinetic and photolysis rates (Stavrakou et al., 2009a).

Anthropogenic NMVOC emissions are obtained from the EDGAR v3.3 database for 1997 (Olivier et al., 2001), vegetation fire emissions from the GFEDv2 database (van der Werf et al., 2006), and isoprene emissions from the MEGANECMWF inventory (Müller et al., 2008). A diurnal fire profile based on Giglio (2007) is applied to the diurnal cycle calculations (Stavrakou et al., 2009a). Further, the largescale fire injection heights are obtained from Dentener et al. (2006).

Prescribed monthly mean climatological $\mathrm{OH}$ fields from Spivakovsky et al. (2000) are used to test the influence of $\mathrm{OH}$ on the calculated $\mathrm{HCHO}$ columns.

The HCHO columns have been calculated with and without accounting for the averaging kernels of the measured FTIR and MAX-DOAS columns.

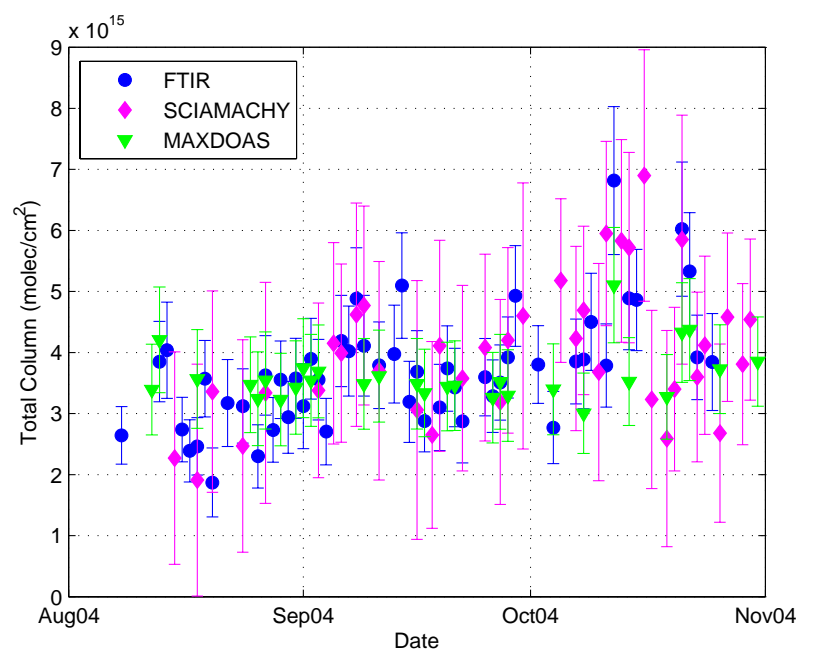

Fig. 8. Daily means of formaldehyde total columns above SaintDenis from FTIR, MAX-DOAS and SCIAMACHY measurements during the 2004 campaign.

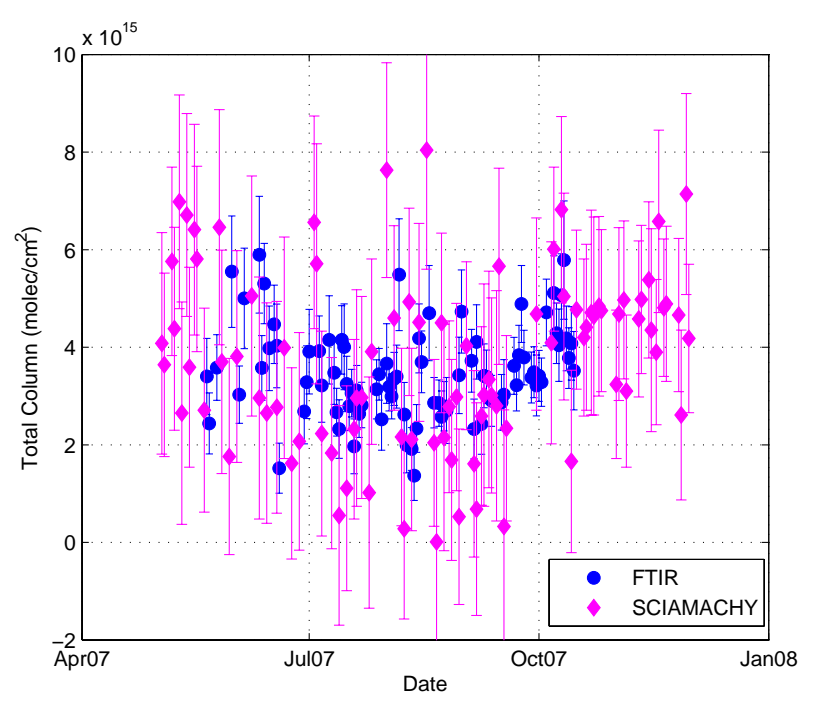

Fig. 9. Formaldehyde daily mean FTIR total columns and daily averaged SCIAMACHY columns in a region of $500 \mathrm{~km}$ around SaintDenis during the 2007 campaign.

The chemical simulations are conducted for 2004, 2005, and 2007 following a 4-month initialization.

\section{Results}

Figure 8 displays the time series of the daily mean total columns of HCHO from FTIR, MAX-DOAS and SCIAMACHY observations in the period common to the FTIR and MAX-DOAS measurements campaigns, i.e., from $\mathrm{Au}-$ gust to November 2004. Analogously, Fig. 9 shows the time series of FTIR and SCIAMACHY daily mean total columns 
during the 2007 FTIR campaign. The error bars represent the total error on the daily mean column, as discussed in Sects. 3.3.2, 4.3.3, and 5, for FTIR, MAX-DOAS and SCIAMACHY, respectively.

The comparisons between FTIR and MAX-DOAS, between FTIR and SCIAMACHY, and between MAX-DOAS and SCIAMACHY, are discussed in Sects. 7.1, 7.2 and 7.3, respectively. In these three sections, we present a statistical analysis of the differences between the daily means total column of the two data sets on coincident days. In order to validate the measurements, the mean and standard deviation of these differences should be compared to the systematic and the random errors on an individual difference, respectively. To calculate the difference between profiles or columns from two different sounders and the error on this difference, we use the formalism of Rodgers and Connor (2003). In each case, we explicitely apply this formalism to direct comparisons, and to corrected comparisons for which the different vertical sensitivity of the data sets is taken into account via their respective averaging kernels.

\subsection{FTIR versus MAX-DOAS}

It can be seen in Fig. 8 that the daily means of FTIR and MAX-DOAS total columns measured on coincident days are in very good agreement, considering their total error bars.

The statistical analysis of the differences between the FTIR and MAX-DOAS measurements has been performed as follows. We have first calculated the direct differences (FTIR-DOAS) for the 24 days of coincident measurements. As FTIR and MAX-DOAS use the same a priori profile, we can directly compare the retrieved profiles without adjusting them for different a priori, as described in Eq. (10) of Rodgers and Connor (2003).

The error covariance matrix of the difference between the retrieved profiles from two different sounders is given by Eq. (13) of Rodgers and Connor (2003). Taking into account that, in our case, (1) the a priori profile $\boldsymbol{x}_{a}$ and the covariance matrix $\mathbf{S}_{\mathrm{var}}$ are the same for FTIR and MAX-DOAS; and (2) the FTIR and MAX-DOAS retrievals use different vertical grids, we calculate the random error covariance matrix $\mathbf{S}_{\delta_{\text {direct }}}^{\text {rand }}$ as follows:

$$
\begin{aligned}
\mathbf{S}_{\delta_{\text {direct }}}^{\text {rand }}= & \mathbf{W}_{21} \mathbf{S}_{1}^{\text {rand }} \mathbf{W}_{21}^{T}+\mathbf{S}_{2}^{\text {rand }} \\
& +\left(\mathbf{W}_{21} \mathbf{A}_{1} \mathbf{W}_{12}-\mathbf{A}_{2}\right)^{T} \mathbf{S}_{\mathrm{var}}\left(\mathbf{W}_{21} \mathbf{A}_{1} \mathbf{W}_{12}-\mathbf{A}_{2}\right),
\end{aligned}
$$

with $\mathbf{A}_{1}$ and $\mathbf{S}_{1}^{\text {rand }}$ the averaging kernel matrix and the random error covariance matrix (noise and forward model parameters errors) for the MAX-DOAS retrievals, $\mathbf{A}_{2}$ and $\mathbf{S}_{2}^{\text {rand }}$ the averaging kernel matrix and the random error covariance matrix (noise and forward model parameters errors) for the FTIR retrievals, $\mathbf{S}_{\text {var }}$ expressed in the FTIR grid, and $\mathbf{W}_{21}$ and $\mathbf{W}_{12}$ the grid transformation matrices defined in Calisesi et al. (2005). As seen for the random error on the FTIR and
MAX-DOAS daily mean total columns, $\mathbf{S}_{1}^{\text {rand }}$ and $\mathbf{S}_{2}^{\text {rand }}$ are the MAX-DOAS and FTIR random error covariance matrices divided respectively by the number of MAX-DOAS and FTIR measurements used in the daily mean comparisons.

The systematic error covariance matrix $\mathbf{S}_{\delta_{\text {direct }}}^{\text {syst }}$ can be calculated as:

$\mathbf{S}_{\delta_{\text {direct }}}^{\text {syst }}=\mathbf{W}_{21} \mathbf{S}_{1}^{\text {syst }} \mathbf{W}_{21}^{T}+\mathbf{S}_{2}^{\text {syst }}$.

Or, as we are interested in the error on total column differences, we can obtain it directly as:

$\Delta \mathrm{TC}_{\delta}^{\text {syst }}=\sqrt{\left(\Delta \mathrm{TC}_{\mathrm{FTIR}}^{\text {syst }}\right)^{2}+\left(\Delta \mathrm{TC}_{\mathrm{DOAS}}^{\text {syst }}\right)^{2}}$.

However, as discussed before, the FTIR measurements are sensitive to the whole partial column below about $20 \mathrm{~km}$, while the MAX-DOAS measurements are sensitive only below $2.5 \mathrm{~km}$. To take this into account, we follow Eq. (28) of Rodgers and Connor (2003) where we smooth the FTIR profile $\boldsymbol{x}_{2}$ with the MAX-DOAS averaging kernels $\mathbf{A}_{1}$, i.e., we degrade the profile with the higher vertical resolution (cf. DOFS FTIR=1.1) to the lower resolution (cf. DOFS MAX$\mathrm{DOAS}=0.7$ ):

$\boldsymbol{x}_{2}^{\text {smooth }}=\boldsymbol{x}_{a}+\mathbf{A}_{1} *\left(\boldsymbol{x}_{2}-\boldsymbol{x}_{a}\right)$.

The random and systematic error covariance matrices on the differences, denoted as $\mathbf{S}_{\delta_{\text {smooth }}}^{\text {rand }}$ and $\mathbf{S}_{\delta_{\text {smooth }}}^{\text {syst }}$, respectively, are calculated according to Eq. (30) of Rodgers and Connor (2003) and Eq. (22) of Calisesi et al. (2005):

$$
\begin{aligned}
\mathbf{S}_{\delta_{\text {smooth }}}^{\text {rand }}= & \mathbf{W}_{21} \mathbf{S}_{1}^{\text {rand }} \mathbf{W}_{21}^{T} \\
+ & \left(\mathbf{W}_{21} \mathbf{A}_{1} \mathbf{W}_{12}\right)^{T} \mathbf{S}_{2}^{\text {rand }}\left(\mathbf{W}_{21} \mathbf{A}_{1} \mathbf{W}_{12}\right) \\
+ & \left(\mathbf{I}_{2}-\mathbf{A}_{2}\right)^{T}\left(\mathbf{W}_{21} \mathbf{A}_{1} \mathbf{W}_{12}\right)^{T} \mathbf{S}_{\mathrm{var}}\left(\mathbf{W}_{21} \mathbf{A}_{1} \mathbf{W}_{12}\right) \\
& \left(\mathbf{I}_{2}-\mathbf{A}_{2}\right) \\
\mathbf{S}_{\delta_{\text {smooth }}}^{\text {syst }} & \mathbf{W}_{21} \mathbf{S}_{1}^{\text {syst }} \mathbf{W}_{21}^{T} \\
+ & \left(\mathbf{W}_{21} \mathbf{A}_{1} \mathbf{W}_{12}\right)^{T} \mathbf{S}_{2}^{\text {syst }}\left(\mathbf{W}_{21} \mathbf{A}_{1} \mathbf{W}_{12}\right)
\end{aligned}
$$

with $\mathbf{I}_{2}$ the identity matrix on the FTIR grid. We have expressed all matrices on the FTIR retrieval grid, because it is the coarser grid (below $10 \mathrm{~km}$ ) and therefore the interpolation errors are smaller.

Table 4 summarizes the comparisons between the FTIR and MAX-DOAS data sets in 2004. The table lists the weigthed mean differences and standard deviations, as well as the mean values for the random and systematic errors on the differences.

Confirming the good agreement seen in Fig. 8, the mean difference FTIR-DOAS lies within the systematic error, and the standard deviation is close to the random error. We see from Table 4 the expected effect of the averaging kernels on the comparisons: the standard deviation of the difference is significantly decreased, as well as the random error on the 
Table 4. Weigthed mean differences, and standard deviations, (1) between the FTIR and MAX-DOAS daily mean total columns, and (2) between the FTIR "smoothed total columns" (calculated from the FTIR profiles which have been smoothed with the MAXDOAS averaging kernels) and the MAX-DOAS daily mean total columns. The mean of the random and systematic errors on the differences are also given. All values are in \%.

\begin{tabular}{llll}
\hline Comparisons & $\begin{array}{l}\text { Mean } \pm \text { Std } \\
{[\%]}\end{array}$ & $\begin{array}{l}\text { Systematic } \\
\text { error [\%] }\end{array}$ & $\begin{array}{l}\text { Random } \\
\text { error [\%] }\end{array}$ \\
\hline FTIR - DOAS & $-0.3 \pm 18.3$ & 13.1 & 26.4 \\
FTIR $_{\text {smooth }}$ - DOAS & $-8.4 \pm 7.8$ & 10.0 & 4.7 \\
\hline
\end{tabular}

difference. While the mean of the differences still lies within the systematic error, we see that the standard deviation is slightly larger than the random error, probably due to the errors associated with the grid conversions, as discussed in Calisesi et al. (2005).

\subsection{FTIR versus SCIAMACHY}

Figures 8 and 9 show the daily mean FTIR total columns compared to the daily SCIAMACHY columns in a region of $500 \mathrm{~km}$ around Saint-Denis, during the two FTIR campaigns in 2004 and 2007, respectively. The agreement between FTIR and SCIAMACHY total columns is very good: their values coincide within the given errors bars. The day-to-day variability is well reproduced by both instruments, as seen for example in Fig. 8 for the especially low total columns in mid-August 2004 or the very high values in mid-October 2004. We see in Fig. 9 that both instruments show the same seasonal behaviour with a minimum in August-September. We note that, due to larger cloud contamination, the SCIAMACHY errors are larger in 2007 than in 2004, as already mentioned in Sect. 5.

For the 21 and 28 coincidences in 2004 and 2007, respectively, the statistical analysis of the differences between FTIR and SCIAMACHY HCHO total columns has been performed as follows. Since the retrievals have used different a priori profiles, we adjust the two retrieved products to a comparison ensemble $\boldsymbol{x}_{c}$ by adding to each of them the term $\left(\mathbf{A}_{i}-\mathbf{I}\right)\left(\boldsymbol{x}_{a i}-\boldsymbol{x}_{c}\right)$ (Rodgers and Connor, 2003). We have chosen $\boldsymbol{x}_{c}$ to be the a priori FTIR profile $\boldsymbol{x}_{a, \mathrm{FTIR}}=\boldsymbol{x}_{a}$. The SCIAMACHY retrievals have been made using a zero linearization point (De Smedt et al., 2008, following the work of Eskes and Boersma, 2003), thus $\boldsymbol{x}_{a, \mathrm{SCIA}}=0$. So, the FTIR retrieval products to be used for comparisons remain unchanged while we have to add the term $\left(\mathbf{A}_{\mathrm{SCIA}}-\mathbf{I}\right)\left(0-\boldsymbol{x}_{a}\right)$ to the SCIAMACHY products. Therefore, the SCIAMACHY total columns for comparison $c_{1}^{\text {compar }}$ become:

$c_{1}^{\mathrm{compar}}=c_{1}+c_{a}-\boldsymbol{a}_{1}^{T} \boldsymbol{x}_{a}^{\mathrm{pc}}$, in which $c_{1}$ is the retrieved SCIAMACHY total column, $\boldsymbol{a}_{1}$ the associated total column averaging kernel, $c_{a}$ the FTIR a priori total column and $\boldsymbol{x}_{a}^{\mathrm{pc}}$ the FTIR a priori profile of layers partial columns, expressed in $\mathrm{mol} / \mathrm{cm}^{2}$.

The direct difference between both instruments is then:

$\delta_{\text {direct }}=c_{2}-c_{1}-c_{a}+\boldsymbol{a}_{1}^{T} \boldsymbol{x}_{a}^{\mathrm{pc}}$,

$c_{2}$ being the FTIR retrieved total column.

The variance of this difference is given by Eq. (24) of Rodgers and Connor (2003). If we decompose it into its random and systematic components, we have:

$$
\begin{aligned}
\left(\sigma_{\text {direct }}^{\text {rand }}\right)^{2}= & \left(\sigma_{1}^{\text {rand }}\right)^{2}+\left(\sigma_{2}^{\text {rand }}\right)^{2} \\
& +\left(\boldsymbol{a}_{1}-\boldsymbol{a}_{2}\right)^{T} \mathbf{S}_{\mathrm{var}}^{\mathrm{pc}}\left(\boldsymbol{a}_{1}-\boldsymbol{a}_{2}\right) \\
\left(\sigma_{\text {direct }}^{\text {syst }}\right)^{2}= & \left(\sigma_{1}^{\text {syst }}\right)^{2}+\left(\sigma_{2}^{\text {syst }}\right)^{2},
\end{aligned}
$$

where $\boldsymbol{a}_{2}$ is the FTIR total column averaging kernel and $\mathbf{S}_{\mathrm{var}}^{\mathrm{pc}}$ is expressed in the FTIR grid and in partial column units. $\boldsymbol{a}_{1}$ can easily be interpolated in the FTIR grid, since it is independent of the layer width in case of SCIAMACHY.

As in the previous section, in order to take into account the difference in vertical sensitivity of both instruments, we calculate the "smoothed FTIR total columns" following Eq. (12):

$c_{2}^{\text {smooth }}=c_{a}+\boldsymbol{a}_{1}^{T} \cdot\left(\boldsymbol{x}_{2}^{\mathrm{pc}}-\boldsymbol{x}_{a}^{\mathrm{pc}}\right)$,

with $\boldsymbol{x}_{2}^{\mathrm{pc}}$ the FTIR retrieved profile expressed in partial column units.

The difference between the smoothed FTIR total column and the SCIAMACHY total columns is then, combining Eqs. (15) and (19):

$\delta_{\text {smooth }}=\boldsymbol{a}_{1}^{T} * \boldsymbol{x}_{2}^{\mathrm{pc}}-c_{1}$.

The variance of this difference is given by Eq. (27) of Rodgers and Connor (2003). If we separate the random and systematic component, we obtain:

$$
\begin{aligned}
\left(\sigma_{\text {smooth }}^{\text {rand }}\right)^{2}= & \left(\sigma_{1}^{\text {rand }}\right)^{2}+\boldsymbol{a}_{1}^{T} \mathbf{S}_{2}^{\text {rand,pc }} \boldsymbol{a}_{1} \\
& +\boldsymbol{a}_{1}^{T}\left(\mathbf{I}_{2}-\mathbf{A}_{2}^{\mathrm{pc}}\right) \mathbf{S}_{\mathrm{var}}^{\mathrm{pc}}\left(\mathbf{I}_{2}-\mathbf{A}_{2}^{\mathrm{pc}}\right)^{T} \boldsymbol{a}_{1} \\
\left(\sigma_{\text {smooth }}^{\text {syst }}\right)^{2}= & \left(\sigma_{1}^{\text {syst }}\right)^{2}+\boldsymbol{a}_{1}^{T} \mathbf{S}_{2}^{\text {syst,pc }} \boldsymbol{a}_{1},
\end{aligned}
$$

where $\mathbf{A}_{2}^{\mathrm{pc}}$ and $\mathbf{S}_{2}^{\mathrm{pc}}$ are the FTIR averaging kernel and error covariance matrices, expressed in partial column units.

The comparison between FTIR and SCIAMACHY columns is summarized in Table 5, for the 2004 and 2007 campaigns. The agreement is very good in 2004: the means of the differences are within the systematic error for both direct and FTIR smoothed comparisons, and the standard deviations correspond nicely to the random error budget. In 2007, the means are still within the systematic errors but the 
Table 5. Weigthed mean differences, and standard deviations, (1) between the ground-based (FTIR or MAX-DOAS) and SCIAMACHY daily mean total columns, and (2) between the groundbased "smoothed total columns" (calculated from the FTIR (or MAX-DOAS) profiles which have been smoothed with the SCIAMACHY total column averaging kernels) and the SCIAMACHY daily mean total columns. The mean of the random and systematic errors on the differences are also given. All values are in \%.

\begin{tabular}{lcll}
\hline Comparisons & $\begin{array}{l}\text { Mean } \pm \text { Std } \\
{[\%]}\end{array}$ & $\begin{array}{l}\text { Systematic } \\
\text { error [\%] }\end{array}$ & $\begin{array}{l}\text { Random } \\
\text { error [\%] }\end{array}$ \\
\hline FTIR - SCIA 2004 & $-4.6 \pm 20.3$ & 39.9 & 22.1 \\
FTIR $_{\text {smooth }- \text { SCIA }}$ & $-3.6 \pm 20.6$ & 39.8 & 21.7 \\
FTIR - SCIA 2007 $+17.0 \pm 54.3$ & 56.8 & 37.0 \\
FTIR $_{\text {smooth - SCIA }}$ & $+18.1 \pm 54.4$ & 56.5 & 35.4 \\
DOAS - SCIA $_{\text {DOAS }}$ & $-11.2 \pm 30.5$ & 42.3 & 30.6 \\
Smooth - SCIA & $-16.9 \pm 31.0$ & 42.3 & 32.5 \\
\hline
\end{tabular}

observed standard deviations (about 54\%) are larger than the random errors (only about 35\%). One explanation can be given for the latter discrepancy. The SCIAMACHY total columns being spatial averages, a geolocation error exists, which is not taken into account. This could have a larger effect in 2007, when the number of pixels included in the daily means is reduced due to enhanced cloud fractions.

We notice also from Table 5, that the smoothing of the FTIR profiles with the SCIAMACHY total column averaging kernels does not significantly improve the comparisons. This is probably due to the fact that both instruments have similar total column averaging kernels, as illustrated in Fig. 10.

\subsection{MAX-DOAS versus SCIAMACHY}

Although the total column averaging kernels, given in Fig. 10, show that MAX-DOAS and SCIAMACHY instruments have a maximum sensitivity to formaldehyde in two different parts of the atmosphere (0-2 km for MAX-DOAS and above $2 \mathrm{~km}$ for SCIAMACHY), the comparison of both data sets is found to be relevant because (1) between 0 and $2 \mathrm{~km}$ of altitude both total column averaging kernels are at least in the 0.3-0.8 range (see Fig. 10), and (2) about $40 \%$ of the formaldehyde total column is present in this altitude range.

The time series of MAX-DOAS and SCIAMACHY total columns from August 2004 to August 2005 are depicted in Fig. 11. It can be seen that the MAX-DOAS time series of total columns shows a smaller day-to-day variability than the SCIAMACHY one. This could be explained by the fact that MAX-DOAS measurements underestimate the variability of formaldehyde above $2 \mathrm{~km}$, while SCIAMACHY tends to overestimate it above $3 \mathrm{~km}$ (total column averaging kernels larger than 1). We can note that the FTIR total col-

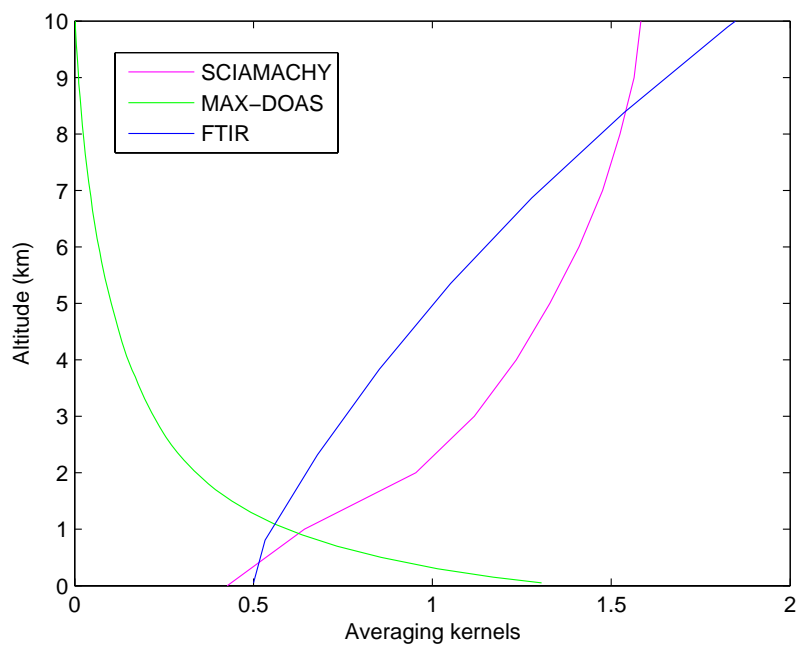

Fig. 10. FTIR, MAX-DOAS and SCIAMACHY total column averaging kernels.

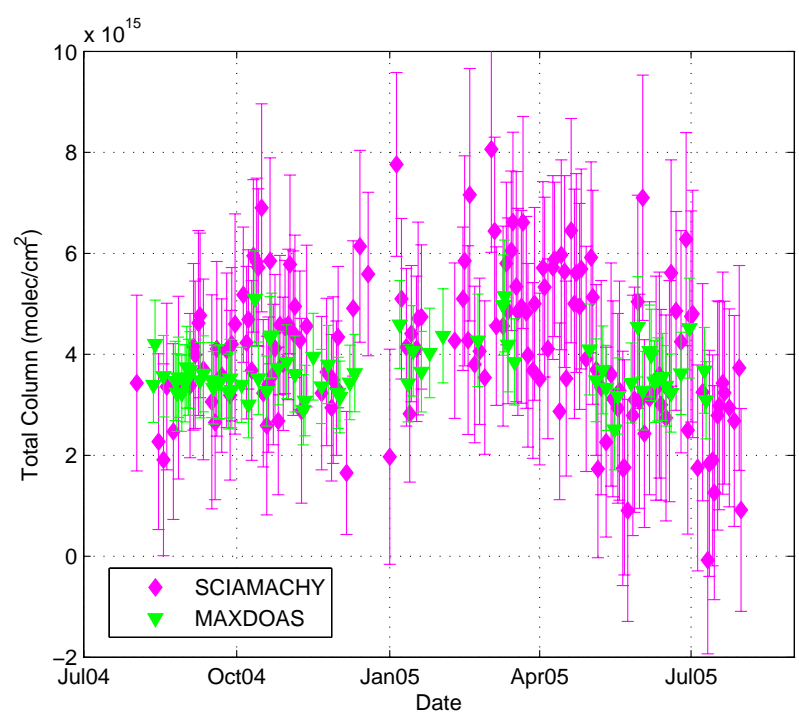

Fig. 11. Daily means of formaldehyde total columns above SaintDenis from MAX-DOAS and SCIAMACHY measurements from August 2004 to August 2005.

umn averaging kernel is larger than 1 above $5 \mathrm{~km}$ (Fig. 10), which means that the FTIR variability could also be overestimated. Above this altitude only about $24 \%$ of the formaldehyde total column is present (and only $10 \%$ above $10 \mathrm{~km}$ ), thus the effect on the total column variability should not be too large. However, the effect of underestimation of the variability for MAX-DOAS and overestimation for FTIR is taken into account in their respective error bars via the smoothing error. One should keep in mind that this smoothing error has been calculated with our best estimate of the formaldehyde natural variability (PEM-Tropics-B measurements, see Sect. 2) which could be an underestimation of the variability 
Table 6. Performed simulations.

S1 Standard

S2 Use OH fields from Spivakovsky et al. (2000)

S3 Use Cl fields in MBL from Allan et al. (2007)

at Réunion Island: as discussed in the following Sect. 8, Réunion Island is affected by long-range transport of $\mathrm{HCHO}$ precursors from Madagascar.

Using the same formalism as in Sect. 7.2, we give in Table 5 the statistical analysis and error budget for the MAXDOAS and SCIAMACHY comparisons. The agreement is reasonably good with weighted mean and standard deviation of the differences between "MAX-DOAS smoothed" and SCIAMACHY total columns of $-16.9 \pm 31.0 \%$. The standard deviation corresponds nicely to the random error on the difference $(32.5 \%)$.

\subsection{FTIR and MAX-DOAS versus IMAGESv2}

The FTIR and MAX-DOAS HCHO daily mean total columns are compared in Figs. 12 and 13 to the formaldehyde columns simulated by the IMAGESv2 model and interpolated for the measurement site. The performed model simulations are summarized in Table 6. The sensitivity run $\mathrm{S} 2$ is motivated by the important role played by the hydroxyl radical $(\mathrm{OH})$. The oxidation of methane by $\mathrm{OH}$ is by far the largest source of formaldehyde in the troposphere, in particular over remote areas. The simulation S3 includes the oxidation of methane by chlorine atoms in the marine boundary layer (MBL), which could account for about $5 \%$ of the global tropospheric sink of methane according to an estimation based on isotopic measurements (Allan et al., 2007). The chlorine concentrations in the MBL are parameterized as in Allan et al. (2007) as a function of latitude and season, with an annual average of $18 \times 10^{3} \mathrm{molcm}^{-3}$ and a large seasonal cycle. The chemistry of chlorine has been considered previously as a possible explanation for the underestimation of modeled formaldehyde and peroxy radical concentrations against ship measurements in the Indian ocean (Burkert et al., 2003; Wagner et al., 2002).

Model results obtained in simulations $\mathrm{S} 1$ and $\mathrm{S} 2$ are shown in Figs. 12 and 13. In both cases, the averaging kernels of the instruments were applied to the modeled profiles in the determination of the total column. For illustration purposes, vertical columns calculated without taking the averaging kernels into account are also shown. The results of simulation S3 are omitted since they are found to differ only very marginally from simulation S1. More precisely, although the formaldehyde production due to the presence of chlorine in the MBL increases the formaldehyde concentration by $5-15 \%$ at surface level, its impact on the total column is only $1-2 \%$ (taking the averaging kernels into account).
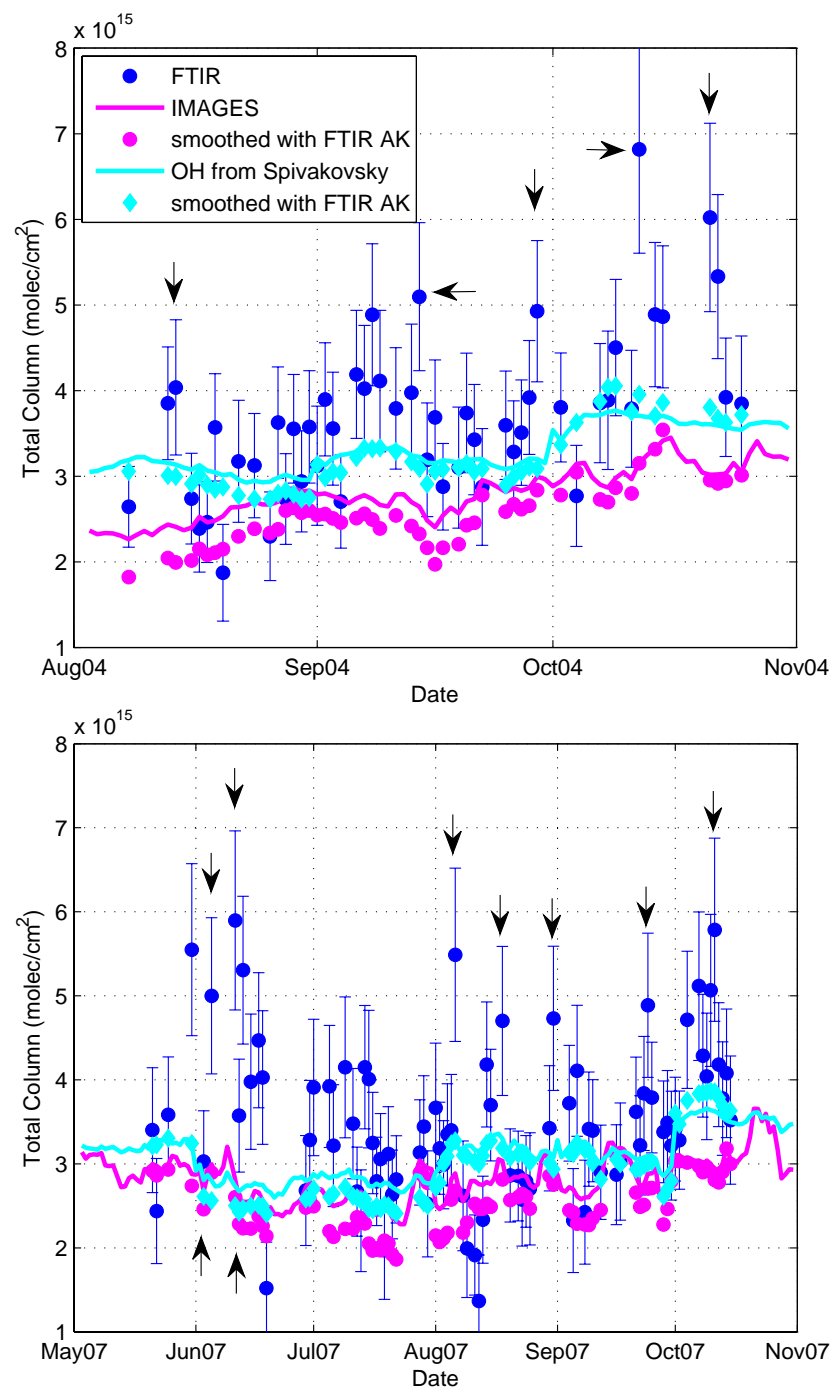

Fig. 12. FTIR and IMAGESv2 ( $\mathrm{S} 1$ in magenta; $\mathrm{S} 2$ in cyan) formaldehyde total columns during the two FTIR campaigns in 2004 (top) and 2007 (bottom). The arrows correspond to dates mentioned in the discussion (Sect. 8): the 14 August, 14 and 29 September, 12 and 21 October 2004 (top plot); and the 3, 5, 11 and 12 June, 6, 18, and 31 August, 24 September, and 11 October 2007 (bottom plot).

Table 7 summarizes the results of the comparisons for the two campaigns of FTIR measurements in 2004 and 2007 (52 and 84 coincidences, respectively), and for the MAX-DOAS campaign measurements (70 coincidences).

\section{Discussion}

Réunion Island, being a small island located in the Indian Ocean, can be seen as a remote marine site where the methane oxidation is the dominant formaldehyde source. However, it is situated only $700 \mathrm{~km}$ from the East coast of 


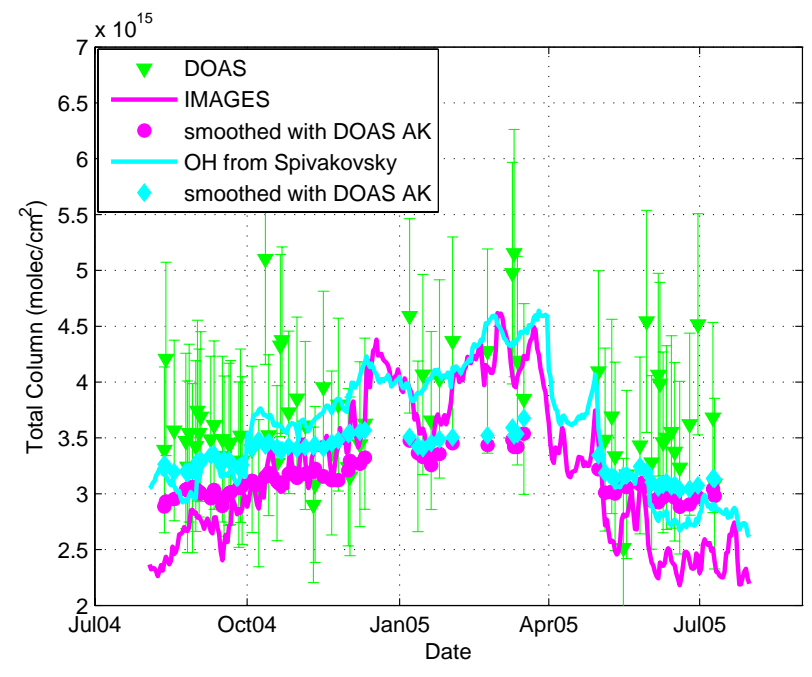

Fig. 13. MAX-DOAS and IMAGESv2 formaldehyde total columns.

Madagascar and about $2000 \mathrm{~km}$ from southeastern Africa, regions with large biogenic NMVOC emissions as well as extensive vegetation fires during the May-November period. Although formaldehyde itself has a too short lifetime (a few hours) to be directly transported over such distances, pyrogenic and biogenic NMVOC precursors (e.g. ethane, methanol, acetic acid, etc.) and oxidation products (e.g. certain organic nitrates, hydroperoxides, etc.) can be transported to Réunion Island and lead to enhanced formaldehyde formation.

As seen in Figs. 9 and 11, ground-based and SCIAMACHY measurements show a minimum of formaldehyde in local winter, which is also found in the IMAGESv2 model (Figs. 12 and 13). This minimum is primarily due to the lower radiation and humidity levels prevailing during this period, which lead to lower $\mathrm{OH}$ concentrations and therefore to lower methane oxidation rates. The model predicts a maximum of formaldehyde in January-March (Fig. 13), also found in the MAX-DOAS and SCIAMACHY measurements (Fig. 11). Unfortunately, only few ground-based measurements are available in this period due to the prevalence of cloudy conditions.

However, discrepancies are found regarding the amplitude of the seasonal variations: for example, the FTIR columns increase by about $50-60 \%$ between July-August and October, whereas the modeled values (taking FTIR averaging kernels into account) increase by about $40 \%$ in the same time period (Fig. 12). The MAX-DOAS measurements show a smaller seasonal amplitude (about 30\%, Fig. 13), primarily because of the rather low degrees of freedom for signal $(\mathrm{DOFS}=0.7$ ) and the fact that MAX-DOAS is sensitive only below $2.5 \mathrm{~km}$. This is confirmed in Fig. 13 where we see that the amplitude of the modeled seasonal cycle is strongly reduced by the application of the MAX-DOAS averaging kernels.
Table 7. Weigthed mean differences, and standard deviations (in \%), between the ground-based and the modeled HCHO total columns. In all cases, the averaging kernels of the instruments were applied in the calculation of the simulated columns.

\begin{tabular}{lc}
\hline Comparisons & Mean \pm Std [\%] \\
\hline FTIR - IMAGES S1 2004 & $30.5 \pm 22.1$ \\
FTIR - IMAGES S2 2004 & $8.5 \pm 19.6$ \\
FTIR - IMAGES S1 2007 & $25.0 \pm 26.9$ \\
FTIR - IMAGES S2 2007 & $9.4 \pm 25.5$ \\
DOAS - IMAGES S1 & $14.5 \pm 12.7$ \\
DOAS - IMAGES S2 & $8.0 \pm 12.9$ \\
\hline
\end{tabular}
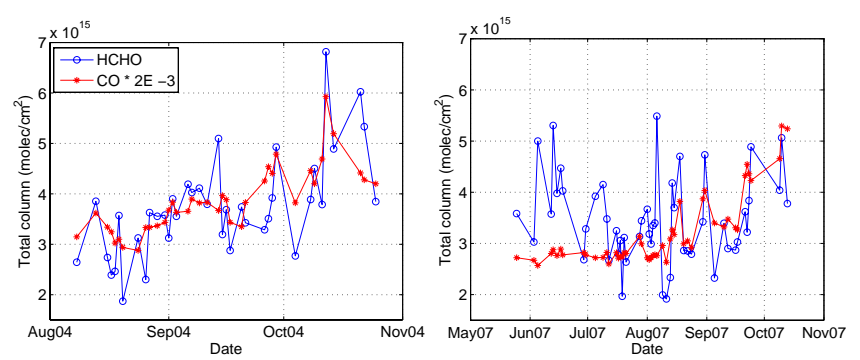

Fig. 14. Daily means of FTIR HCHO (in blue) and CO (in red) (Senten et al., 2008) total columns at Réunion Island in 2004 (left) and 2007 (right). The CO total columns have been multiplied by a factor $2 \times 10^{-3}$. Only coincident days are shown.

Both the FTIR and SCIAMACHY total columns show a high day-to-day variability (Figs. 8 and 9), which is not captured by the model. The largest disagreements between FTIR and the model appear in October 2004 and in June 2007. The day-to-day variability of the MAX-DOAS columns is also higher than in the model, e.g. in June 2005, when values above $4 \times 10^{15} \mathrm{~mol} / \mathrm{cm}^{2}$ are found (Fig. 13) while the modeled values are at their minimum (around $3 \times 10^{15} \mathrm{~mol} / \mathrm{cm}^{2}$ ).

The large temporal variability of FTIR formaldehyde columns might be partly elucidated by their good correlation (0.7) with CO total columns measured with the same instrument (Senten et al., 2008) during the period from August to November, when the fire season is at its maximum in southeastern Africa and Madagascar (see Fig. 14). This result suggests that long-range transport of $\mathrm{HCHO}$ precursors from these regions can explain the large temporal variability of observed HCHO columns. The general underestimation of the modeled columns against FTIR measurements (by ca. $25 \%$ on average, see Table 7) would therefore reflect either an underestimation of NMVOC emissions in Southeast Africa and Madagascar in the model, or an underestimation of the role of long-range transport from these source regions to the measurement site. This interpretation is consistent with the comparatively lower bias found between the model and the MAX-DOAS measurements, since the DOAS 
technique is mostly sensitive to the lowermost atmospheric layers (below $2.5 \mathrm{~km}$ ), where long-range transport is ineffective (see below).

To assess the role of long-range transport on the observations at Réunion Island, we used the Lagrangian particle dispersion model FLEXPART v.6.2 (Stohl et al., 2005). The model was driven by 3 -hourly $1^{\circ} \times 1^{\circ}$ windfields from ECMWF. For this study, for each day during our measurement campaign, the model released 1 million particles between 0-10 km above Saint-Denis at 05:00 UT. Backward trajectories were calculated using a $\mathrm{CO}$ tracer. The calculated backward trajectory output (i.e., the response function) is related to the particles residence time in the output grid cells. In our case the response function $\left(\mathrm{sm}^{3} \mathrm{~kg}^{-1}\right)$ at a given location equals the residence time divided by the local total air mass concentration. When multiplying by a 3-D field of emission mass fluxes $\left(\mathrm{kgm}^{-3} \mathrm{~s}^{-1}\right)$, one can derive the strength of the contribution of a particular location (source strength) to the observations at Réunion Island at a given time. We use $\mathrm{CO}$ as a qualitative proxy for the emissions of $\mathrm{HCHO}$ and its precursors. The $\mathrm{CO}$ emission fluxes were obtained from the GFEDv2 fire emission database. Apart from its limited temporal resolution (8 days) and intrinsic uncertainties, an additional major uncertainty is the emission injection height. At Réunion Island, the dominant transport pathway at low altitudes (below $4 \mathrm{~km}$ during most of the fire season) originates from the South-East (Taupin et al., 1999). At these low altitudes, African-Madagascar emissions reach Réunion Island only via a roundabout way. Given the short lifetime of $\mathrm{HCHO}$ and of its pyrogenic precursors that could be emitted by fires (a few hours to a few days) it is unlikely that these pathways contribute significantly to the observed $\mathrm{HCHO}$ concentrations. Above $4 \mathrm{~km}$, the air masses generally take a direct eastward pathway (Taupin et al., 1999) and any African-Madagascar emissions that reach this altitude band are transported within a short timeframe towards Réunion Island. To assess the emission injection heights and the timescales at which the transport events take place, we have calculated the $\mathrm{CO}$ tracer volume mixing ratio detected at Réunion Island for different backward trajectory runtimes. It was found that the best correlation between the observed $\mathrm{HCHO}$ and simulated $\mathrm{CO}$ data was obtained when restricting the runtime to $\simeq 1$ day and by allowing emission into the $4-6 \mathrm{~km}$ altitude layer. The IMAGESv2 model uses the same emission height distribution as given by Dentener et al. (2006) and the EDGAR database (Olivier et al., 2001), setting the top emission height for large scale wild-fires from Madagascar at $1 \mathrm{~km}$. However, according to Freitas et al. (2007), injection heights above $4 \mathrm{~km}$ are certainly attainable, even for African Savanna fires. An alternative explanation is the potential underestimation of vertical (convective or other) transport within the FLEXPART model itself (to simulate moist convection, FLEXPART uses the convective parameterization scheme by Emanuel and Živković-Rothman, 1999). Such an underestimation of vertical transport pro- cesses can only be offset by allowing an overestimation of high altitude emissions in the model run.

Due to the various uncertainties (limited temporal resolution of GFEDv2 database, CO used as a proxy, transport in FLEXPART), we give here qualitative examples only, of how emissions followed by transport to Réunion correlate with the high peak values of FTIR HCHO total columns. Within the 1 day backward trajectory, the FLEXPART simulations indicate that emissions/transport originate from Madagascar only. Longer runtimes yielded lower correlations, indicating that sources further inland do not significantly contribute to the observations at Réunion Island.

During the 2004 campaign, we can observe from Fig. 12 that for example the 13 and 14 August are days with high $\mathrm{HCHO}$ values compared to the previous and following days (8th and 16th). The results of the FLEXPART simulations (1 day backward trajectories) for those four days are shown in Fig. 15. FLEXPART calculates indeed a significant contribution of Madagascar emissions to the observed signal at Réunion Island on the 13th and 14th, while no transport is seen on the 8th and 16th. Using 3 days backward trajectories, we observe (not shown) that the transport patterns of pyrogenic $\mathrm{CO}$ from Africa are not associated with any enhancement in $\mathrm{HCHO}$, presumably because of the short lifetimes of its precursors. Similarly, we observe high HCHO events on 14 and 29 September as well as 12 October, that are well reproduced by FLEXPART (not shown). On the contrary, the 21-22 October peaks in 2004 are missed by FLEXPART, and are not seen in the FTIR CO measurements (Fig. 14). Note that MAX-DOAS and SCIAMACHY also show higher values of HCHO on the 21-22 October (see Fig. 8). It can be speculated that these enhancements appear below $2.5 \mathrm{~km}$, and are due to local sources, which would explain that FLEXPART and the FTIR CO measurements miss them.

Similarly, the HCHO peaks in August-November 2007 can be explained using FLEXPART simulations. We show as an example in Fig. 15 the well isolated peak observed on the 6 August (Fig. 12). The peak values of 18 and 31 August, and 24 September 2007 (Fig. 12) are also well reproduced by FLEXPART (not shown). On the contrary, the peak value of 11 October 2007 is not explained by FLEXPART, but an enhancement of $\mathrm{CO}$ is also seen on this day by FTIR measurements (Fig. 14).

However, we note that there is hardly any correlation between the observed FTIR's CO and HCHO in May-July 2007 (see Fig. 14), suggesting that the long-range transport of biomass burning plumes could not be the only explanation to the large temporal variability of FTIR columns. We give in Fig. 16 the biomass fire emissions of $\mathrm{CO}$ observed at Madagascar during 2004 and 2007 as given by the GFEDv2 database. While the fire intensity peaks in September-October, there are indeed ample fires throughout the whole FTIR measurement campaign. As illustrated in Fig. 15 with an example of FTIR data in June, FLEXPART 

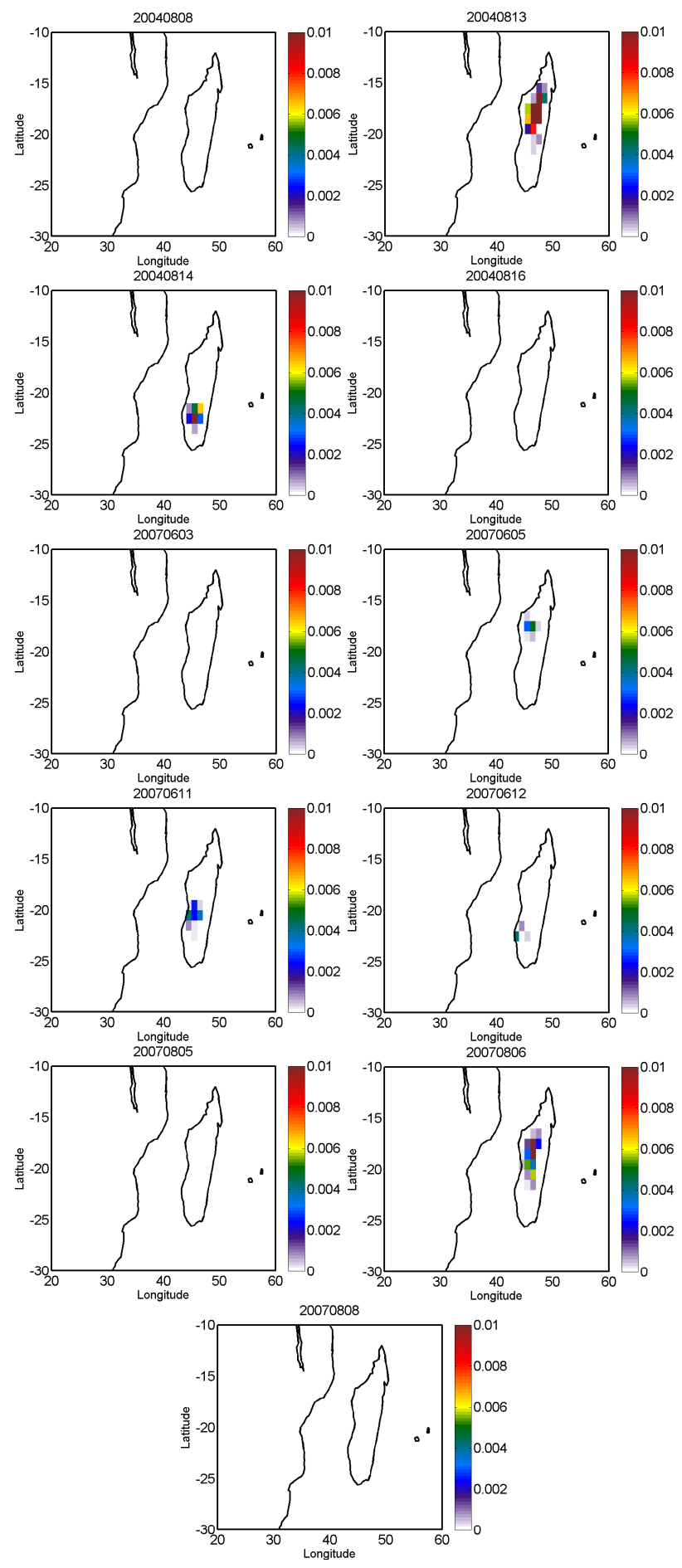

Fig. 15. CO tracer source strength (in ppb) as obtained from FLEXPART/GFEDv2, after a 1 day backward run. The total emission mass flux has been evenly distributed between 0 and $6 \mathrm{~km}$. See text for details. Réunion Island is the closest island to the East of Madagascar.

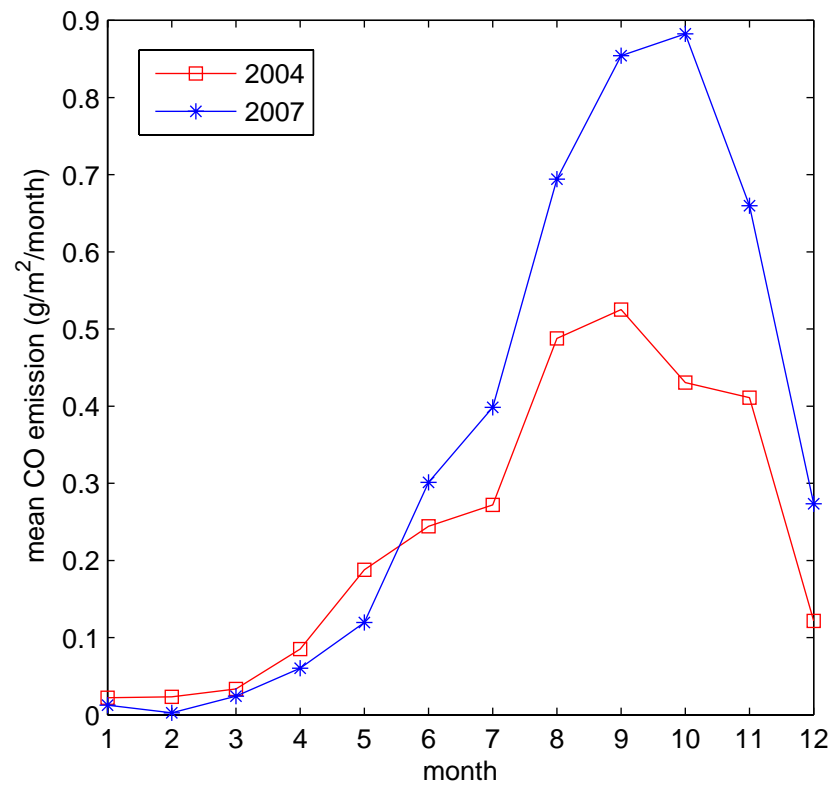

Fig. 16. Average $\mathrm{CO}$ emission source strength from biomassburning in Madagascar (in $\mathrm{gm}^{-2} \mathrm{month}^{-1}$ ), as derived from the GFEDv2 database.

explains the observed day-to-day variability (Fig. 12): a low $\mathrm{HCHO}$ value on the $3 \mathrm{rd}$, high values on the 5th and 11th, and again smaller values on the 12th. An explanation for the absence of correlation with FTIR CO, is that CO's lifetime is much larger than that of $\mathrm{HCHO}$, and therefore will be primarily impacted by the global fluctuation and accumulation of biomass burning emissions, which are more important in August-November period.

In conclusion, it appears plausible that both the large temporal variability of observed $\mathrm{HCHO}$ columns and the general underestimation of HCHO columns by the IMAGESv2 model in comparison with FTIR data (Fig. 12) are primarily caused by an underestimated contribution of Madagascar emissions to the signal measured at Réunion Island. Uncertainties in the determination of $\mathrm{OH}$ concentrations in the model might also possibly contribute to the underestimation, as suggested by the results of simulation $\mathrm{S} 2$ given in Table 7: the biases between ground-based and modelled total columns are reduced to $8 \%$ using prescribed $\mathrm{OH}$ fields. The role of chlorine-initiated methane oxidation appears to be very small in this context (simulation S3). Pyrogenic and biogenic NMVOC emissions might be largely underestimated in the model in South-East Africa, as indicated by an inverse modeling study based on SCIAMACHY data (Stavrakou et al., 2009b). The fire injection heights and the convective updraft fluxes used in the model are also very uncertain. 


\section{Conclusions}

Ground-based FTIR and MAX-DOAS daily mean total columns of formaldehyde have been retrieved during campaign measurements, in 2004 and 2007, and in 2004-2005, respectively, at the NDACC site of Réunion Island $\left(21^{\circ} \mathrm{S}\right.$, $\left.55^{\circ} \mathrm{E}\right)$. The two data sets are compared in the common measurement period August to October 2004. FTIR and MAXDOAS total columns have also been compared to correlative SCIAMACHY data. The comparisons include an error analysis, and account for differences in vertical sensitivities by including the respective averaging kernels. A good agreement is found (no significant bias, standard deviations within the random error budget) between the three instruments except for the FTIR and SCIAMACHY comparisons in 2007 where the standard deviation is larger (54\%). The three instruments show the same seasonal cycle with a minimum in local winter, due to the lower $\mathrm{OH}$ concentrations during this period. However, the MAX-DOAS measurements show a lower seasonal amplitude due to their lack of sensitivity in the free troposphere.

The FTIR HCHO total columns show a high day-to-day variability at Réunion Island, which is correlated with FTIR $\mathrm{CO}$ measurements during the intense fire season in Madagascar in August-November. Simulations performed using the Lagrangian particle dispersion model FLEXPART, allowing emissions into the 4-6 km layer and using 1 day backward trajectory runtimes, explain qualitatively this day-today variability, even in the May-June period where bad correlation is seen between FTIR HCHO and CO. These results indicate an underestimation of the fire emission injection heights as given by EDGAR (Olivier et al., 2001) and/or the underestimation of vertical transport within the FLEXPART model. Quantitative studies would require less uncertainties in the FLEXPART simulations: an increased temporal resolution of the GFEDv2 database (currently 8 days), vertical and horizontal transport, fire injection heights, ...

The FTIR and MAX-DOAS data have also been compared to modeled HCHO columns from the global CTM IMAGESv2. We found that the standard model underestimates HCHO total columns at Réunion Island (biases of 25-31\% and $15 \%$ are obtained with FTIR and MAX-DOAS comparisons, respectively). This could be due to underestimation of $\mathrm{OH}$ concentrations in the model as suggested by a simulation performed using prescribed $\mathrm{OH}$ fields. More probably, the model underestimates the contribution of large-scale transport of $\mathrm{HCHO}$ precursors from Madagascar to Réunion Island. The pyrogenic and biogenic emissions at Madagascar could be underestimated. The fire injection heights and the convective updraft fluxes used in the model might be also too low in the model.

Acknowledgements. We acknowledge for financial support the Belgian Federal Science Policy (AGACC; SSD program, SD/AT/01B), the PRODEX office (SECPEA), the Communauté Française de Belgique (Actions de Recherche Concertées), the
EU (SCOUT-O3), and ESA (TEMIS and PROMOTE). We thank A. Perrin, D. Jacquemart, F. Kwabia Tchana and N. Lacome for providing their new $\mathrm{HCHO}$ spectroscopic linelist before its publication. We are grateful to all people who have participated to the ground-based measurements. We acknowledge J.-L. Baray, R. Delmas, J. Leveau, and G. Clain, from Université de La Réunion, for their collaboration. We thank also G. Dufour for discussion on ACE HCHO measurements above La Réunion.

Edited by: P. Monks

\section{References}

Abbot, D. S., Palmer, P. I., Martin, R. V., Chance, K. V., Jacob, D. J., and Guenther, A.: Seasonal and interannual variability of North American isoprene emissions as determined by formaldehyde column measurements from space, Geophys. Res. Lett., 30(17), 1886, doi:10.1029/2003GL017336, 2003.

Allan, W., Struthers, H., and Lowe, D. C.: Methane carbon isotope effects caused by atomic chlorine in the marine boundary layer, J. Geophys. Res., 112, D04306, doi:10.1029/2006JD007369, 2007.

Anderson, J. P., Clough, S. A., Kneizys, F. X., Chetwynd, J. H., and Shettle, E. P.: AFGL atmospheric constituent profiles (0$120 \mathrm{~km}$ ), AFGL-TR-86-0110, 1986.

Bogumil, K., Orphal, J., Homann, T., Voigt, S., Spietz, P., Fleischmann, O. C., Vogel, A., Hartmann, M., Bovensmann, H., Frerik, J., and Burrows, J. P.: Measurements of molecular absorption spectra with the SCIAMACHY pre-flight model: instrument characterization and reference data for atmospheric remote sensing in the 230-2380 nm region, J. Photochem. Photobiol. A., 157, 167-184, doi:10.1016/S1010-6030(03)00062-5, 2003.

Boersma , K. F., Eskes, H. J., and Brinksma, E. J.: Error analysis for tropospheric $\mathrm{NO}_{2}$ retrieval from space, J. Geophys. Res., 109, D04311, doi:10.1029/2003JD003962, 2004.

Burkert, J., Andrés-Hernández, M. D., Reichert, L., MeyerArnek, J., Doddridge, B., Disckerson, R. R., Mühle, J., Zahn, A., Carsey, T., and Burrows, J. P.: Trace gas and radical diurnal behavior in the maritime boundary layer during INDOEX 1999 , J. Geophys. Res., 108, 8000, doi:10.1029/2002JD002790, 2003.

Calisesi Y., Soebijanta V. T., and van Oss R.: Regridding of remote soundings: Formulation and application to ozone profile comparison, J. Geophys. Res., 110, D23306, doi:10.1029/2005JD006122, 2005.

Cantrell, C. A., Davidson, J. A., McDaniel, A. H., Shetter, R. E., and Calvert, J. G.: Temperature dependent formaldehyde cross sections in the near-ultraviolet spectral region, J. Phys. Chem., 94, 3902-3908, 1990.

Demoulin, P., Zander, R., Mélen, F., Mahieu, E., and Servais, C.: Column abundance measurements of formaldehyde above the Jungfraujoch: in Proceedings of "Atmospheric Spectroscopy Applications 1999”, Reims, France, 1-3 September, 59-62, 1999.

Dentener, F., Kinne, S., Bond, T., Boucher, O., Cofala, J., Generoso, S., Ginoux, P., Gong, S., Hoelzemann, J. J., Ito, A., Marelli, L., Penner, J. E., Putaud, J.-P., Textor, C., Schulz, M., van der Werf, G. R., and Wilson, J.: Emissions of primary aerosol and precursor gases in the years 2000 and 1750 prescribed data-sets for AeroCom, Atmos. Chem. Phys., 6, 4321-4344, 2006, http://www.atmos-chem-phys.net/6/4321/2006/. 
De Smedt, I., Müller, J.-F., Stavrakou, T., van der A, R., Eskes, H., and Van Roozendael, M.: Twelve years of global observations of formaldehyde in the troposphere using GOME and SCIAMACHY sensors, Atmos. Chem. Phys., 8, 4947-4963, 2008, http://www.atmos-chem-phys.net/8/4947/2008/.

Dufour, G., Wittrock, F., Camredon, M., Beekmann, M., Richter, A., Aumont, B., and Burrows, J. P.: SCIAMACHY formaldehyde observations: constraint for isoprene emission estimates over Europe?, Atmos. Chem. Phys., 9, 1647-1664, 2009, http://www.atmos-chem-phys.net/9/1647/2009/.

Emanuel, K. A. and Živković-Rothman, M.: Development and evaluation of a convection scheme for use in climate models, J. Atmos. Sci., 56, 1766-1782, 1999.

Emmons, L. K., Hauglustaine, D. A., Müller, J.-F., Carroll, M. A., Brasseur, G. P., Brunner, D., Staehelin, J., Thouret, V., and Marenco, A.: Data composites of airborne observations of tropospheric ozone and its precursors, J. Geophys. Res., 105, 2049720538, 2000.

Eskes, H. J. and Boersma, K. F.: Averaging kernels for DOAS totalcolumn satellite retrievals, Atmos. Chem. Phys., 3, 1285-1291, 2003, http://www.atmos-chem-phys.net/3/1285/2003/.

Freitas, S. R., Longo, K. M., Chatfield, R., Latham, D., Silva Dias, M. A. F., Andreae, M. O., Prins, E., Santos, J. C., Gielow, R., and Carvalho Jr., J. A.: Including the sub-grid scale plume rise of vegetation fires in low resolution atmospheric transport models, Atmos. Chem. Phys., 7, 3385-3398, 2007, http://www.atmos-chem-phys.net/7/3385/2007/.

Frieß, U., Monks, P. S., Remedios, J. J., Rozanov, A., Sinreich, R., Wagner, T., and Platt, U.: MAX-DOAS $\mathrm{O}_{4}$ measurements: A new technique to derive information on atmospheric aerosols: 2. Modeling studies, J. Geophys. Res., 111, D14203, doi:10.1029/2005JD006618, 2006.

Fu, T.-M., Jacob, D. J., Palmer, P. I, Chance, K., Wang, Y. X., Barletta, B., Blake, D. R., Stanton, J. C., and Pilling, M. J.: Spacebased formaldehyde measurements as constraints on volatile organic compound emissions in East and South Asia, J. Geophys. Res., 112, D06312, doi:10.1029/2006JD007853, 2007.

Giglio, L.: Characterization of the tropical diurnal fire cycle using VIRS and MODIS observations, Remote Sens. Environ., 108, 407-421, 2007.

Grainger, J. F. and Ring, J.: Anomalous Fraunhofer line profiles, Nature, 193, 762, 1962.

Greenblatt, G. D., Orlando, J. J., Burkholder, J. B., and Ravishankara, A. R.: Absorption measurements of oxygen between 330 and 1140 nm, J. Geophys. Res., 95, 18577-18582, 1990.

Hase, F., Blumenstock, T., and Paton-Walsh, C.: Analysis of the instrumental line shape of high-resolution Fourier transform IR spectrometers with gas cell measurements and new retrieval software, Appl. Optics, 38, 3417-3422, 1999.

Hase, F., Demoulin, P., Sauval, A. J., Toon, G. C., Bernath, P. F., Goldman, A., Hannigan, J. W., and Rinsland, C. P.: An empirical line-by-line model for the infrared solar transmittance spectrum from 700 to $5000 \mathrm{~cm}^{-1}$, J. Quant. Spectrosc. Radiat. T., 102, 450-463, 2006.

Heckel, A., Richter, A., Tarsu, T., Wittrock, F., Hak, C., Pundt, I., Junkermann, W., and Burrows, J. P.: MAX-DOAS measurements of formaldehyde in the Po-Valley, Atmos. Chem. Phys., 5, 909918, 2005, http://www.atmos-chem-phys.net/5/909/2005/.

Hendrick, F., Barret, B., Van Roozendael, M., Boesch, H., Butz,
A., De Mazière, M., Goutail, F., Hermans, C., Lambert, J.-C., Pfeilsticker, K., and Pommereau, J.-P.: Retrieval of nitrogen dioxide stratospheric profiles from ground-based zenith-sky UVvisible observations: validation of the technique through correlative comparisons, Atmos. Chem. Phys., 4, 2091-2106, 2004, http://www.atmos-chem-phys.net/4/2091/2004/.

Hendrick, F., Van Roozendael, M., Kylling, A., Petritoli, A., Rozanov, A., Sanghavi, S., Schofield, R., von Friedeburg, C., Wagner, T., Wittrock, F., Fonteyn, D., and De Mazière, M.: Intercomparison exercise between different radiative transfer models used for the interpretation of ground-based zenith-sky and multiaxis DOAS observations, Atmos. Chem. Phys., 6, 93-108, 2006, http://www.atmos-chem-phys.net/6/93/2006/.

Hendrick, F., Van Roozendael, M., Chipperfield, M. P., Dorf, M., Goutail, F., Yang, X., Fayt, C., Hermans, C., Pfeilsticker, K., Pommereau, J.-P., Pyle, J. A., Theys, N., and De Mazière, M.: Retrieval of stratospheric and tropospheric BrO profiles and columns using ground-based zenith-sky DOAS observations at Harestua, 60 N, Atmos. Chem. Phys., 7, 4869-4885, 2007, http://www.atmos-chem-phys.net/7/4869/2007/.

Irie, H., Kanaya, Y., Akimoto, H., Iwabuchi, H., Shimizu, A., and Aoki, K.: First retrieval of tropospheric aerosol profiles using MAX-DOAS and comparison with lidar and sky radiometer measurements, Atmos. Chem. Phys., 8, 341-350, 2008, http://www.atmos-chem-phys.net/8/341/2008/.

Jones, N. B., Riedel, K., Allan, W., Wood, S., Palmer, P. I., Chance, K., and Notholt, J.: Long-term tropospheric formaldehyde concentrations deduced from ground-based fourier transform solar infrared measurements, Atmos. Chem. Phys., 9, 7131-7142, 2009, http://www.atmos-chem-phys.net/9/7131/2009/.

Koelemeijer, R. B. A., Stammes, P., Hovenier, J. W., and de Haan, J. F.: Global distributions of effective cloud fraction and cloud top pressure derived from oxygen A band spectra measured by the Global Ozone Monitoring Experiment: comparison to ISCCP data, J. Geophys. Res., 107(D12), 4151, doi:10.1029/2001JD000840, 2002.

Koelemeijer, R. B. A., de Haan, J. F., and Stammes, P.: A database of spectral surface reflectivity in the range $335-772 \mathrm{~nm}$ derived from 5.5 years of GOME observations, J. Geophys. Res., 108(D2), 4070, doi:10.1029/2002JD002429, 2003.

Martin, R. V., Chance, K., Jacob, D. J., Kurosu, T. P., Spurr, R. J. D., Bucsela, E., Gleason, J. F., Palmer, P. I., Bey, I., Fiore, A. M., Li, Q., Yantosca, R. M., and Koelemeijer, R. B. A.: An improved retrieval of tropospheric nitrogen dioxide from GOME, J. Geophys. Res., 107(D20), 4437, doi:10.1029/2001JD001027, 2002.

Mayer, B. and Kylling, A.: Technical note: The libRadtran software package for radiative transfer calculations - description and examples of use, Atmos. Chem. Phys., 5, 1855-1877, 2005, http://www.atmos-chem-phys.net/5/1855/2005/.

Meier, A., Toon, G. C., Rinsland, C. P., Goldman, A., and Hase, F.: Spectroscopic Atlas of Atmospheric Microwindows in the Middle Infra-Red, 2nd revised edition, IRF Technical Report 048, ISSN: 0284-1738, printed in Sweden, IRF Institutet för Rymdfysik, Kiruna, 2004.

Meller, R. and Moortgat, G. K.: Temperature dependence of the absorption cross-sections of formaldehyde between 223 and $323 \mathrm{~K}$ in the wavelength range $225-375 \mathrm{~nm}$, J. Geophys. Res., 105, 7089-7101, 2000.

Müller, J.-F. and Brasseur, G.: A three-dimensional chemical trans- 
port model of the global troposphere, J. Geophys. Res., 100, 16445-16490, 1995.

Müller, J.-F. and Stavrakou, T.: Inversion of $\mathrm{CO}$ and $\mathrm{NO}_{\mathrm{x}}$ emissions using the adjoint of the IMAGES model, Atmos. Chem. Phys., 5, 1157-1186, 2005, http://www.atmos-chemphys.net/5/1157/2005/.

Müller, J.-F., Stavrakou, T., Wallens, S., De Smedt, I., Van Roozendael, M., Potosnak, M. J., Rinne, J., Munger, B., Goldstein, A., and Guenther, A. B.: Global isoprene emissions estimated using MEGAN, ECMWF analyses and a detailed canopy environment model, Atmos. Chem. Phys., 8, 1329-1341, 2008, http://www.atmos-chem-phys.net/8/1329/2008/.

Neefs, E., De Mazière, M., Scolas, F., Hermans, C., and Hawat, T.: BARCOS, an automation and remote control system for atmospheric observations with a Bruker interferometer, Rev. Sci. Instrum., 78(3), 035109-1 to 035109-8, 2007.

Notholt, J., Toon, G. C., Lehmann, R., Sen, B., and Blavier, J.F.: Comparison of Arctic and Antarctic trace gas column abundances from groud-based Fourier transform infrared spectrometry, J. Geophys. Res., 102, 12863-12869, 1997.

Notholt, J., Toon, G. C., Rinsland, C. P., Pougatchev, N. S., Jones, N. B., Connor, B. J., Weller, R., Gautrois, M., and Schrems, O.: Latitudinal variations of trace gas concentrations measured by solar absorption spectroscopy during a ship cruise, J. Geophys. Res., 105, 1337-1349, 2000.

Notholt, J., Toon, G. C., Jones, N., Griffith, D., and Warneke, T.: Spectral line finding program for atmospheric remote sensing using full radiation transfer, J. Quant. Spectrosc. Radiat. T., 97, 112-125, 2006.

Olivier, J .G. J., Berdowski, J. J. M., Peters, J. A. H. W., Bakker, J., Visschedijk, A. J. H., and Bloos, J.-P. J.: Applications of EDGAR. Including a description of EDGAR 3.0: reference database with trend data for 1970-1995, RIVM report no. 773301 001/ NOP report no. 410200 051, RIVM, Bilthoven, 2001.

Palmer, P. I., Jacob, D. J., Chance, K., Martin, R. V., Spurr, R. J. D., Kurosu, T. P., Bey, I., Yantosca, A., Fiore, A., and Li, Q.: Air-mass factor formulation for spectroscopic measurements from satellites: application to formaldehyde retrievals from GOME, J. Geophys. Res., 106(D13), 14539-14550, doi:10.1029/2000JD900772, 2001.

Perrin, A., Jacquemart, D., Kwabia Tchanab, F., and Lacome, N.: Absolute line intensities measurements and calculations for the 5.7 and $3.6 \mu \mathrm{m}$ bands of formaldehyde, J. Quant. Spectrosc. Radiat. T., 110, 700-716, 2009.

Platt, U. and Stutz, J.: Differential Optical Absorption Spectroscopy (DOAS), Principles and Applications, ISBN 978-3-540-21193-8, Springer, Berlin Heidelberg, Germany, 2008.

Raper, J., Kleb, M., Jacob, D., Davis, D., Newell, R., Fuelberg, H., Bendura, R., Hoell, J., and McNeal, R.: Pacific Exploratory Mission in the Tropical Pacific: PEM-Tropics B, March-April 1999, J. Geophys. Res., 106(D23), 32401-32425, 2001.

Rinsland, C.P., Jones, N. B., Connor, B. J., Logan, J. A., Pougatchev, N. S., Goldman, A., Murcray, F. J., Stephen, T. M., Pine, A. S., Zander, R., Mahieu, E., and Demoulin, P.: Northern and Southern Hemisphere ground-based infrared spectroscopic measurements of tropospheric carbon monoxide and ethane, J. Geophys. Res., 103, 28197-28217, 1998.

Rodgers, C. D.: Inverse methods for atmospheric sounding: The- ory and Practice, Series on Atmospheric, Oceanic and Planetary Physics, Vol. 2, World Scientific Publishing Co., Singapore, 2000.

Rodgers, C. D. and Connor, B. J.: Intercomparison of remote sounding instruments, J. Geophys. Res., 108, 4116-4129, 2003.

Rothman, L. S., Jacquemart, D., Barbe, A., Benner, D. C., Birk, M., Brown, L. R., Carleer, M. R., Chackerian, C., Chance, K., Coudert, L. H., Dana, V., Devi, V. M., Flaud, J.-M., Gamache, R. R., Goldman, A., Hartmann, J. M., Jucks, K. W., Maki, A. G., Mandin, J. Y., Massie, S. T., Orphal, J., Perrin, A., Rinsland, C. P., Smith, M. A. H., Tennyson, J., Tolchenov, R. N., Toth, R. A., Vander Auwera, J., Varanasi, P., and Wagner, G.: The HITRAN 2004 molecular spectroscopic database, J. Quant. Spectrosc. Radiat. T., 96, 139-204, 2005.

Rozanov, A., Rozanov, V., and Burrows, J. P.: A numerical radiative transfer model for a spherical planetary atmosphere: Combined differential integral approach involving the Piccard iterative approximation, J. Quant. Spectrosc. Radiat. T., 69, 491-512, 2001.

Saunders, S. M., Jenkin, M. E., Derwent, R. G., and Pilling, M. J.: Protocol for the development of the Master Chemical Mechanism, MCM v3 (Part A): tropospheric degradation of nonaromatic volatile organic compounds, Atmos. Chem. Phys., 3, 161-180, 2003, http://www.atmos-chem-phys.net/3/161/2003/.

Schofield, R., Kreher, K., Connor, B. J., Johnston, P. V., Thomas, A., Shooter, D., Chipperfield, M. P., Rodgers, C. D., and Mount, G. H.: Retrieved tropospheric and stratospheric BrO columns over Lauder, New Zealand, J. Geophys. Res., 109, D14304, doi:10.1029/2003JD004463, 2004.

Senten, C., De Mazière, M., Dils, B., Hermans, C., Kruglanski, M., Neefs, E., Scolas, F., Vandaele, A. C., Vanhaelewyn, G., Vigouroux, C., Carleer, M., Coheur, P. F., Fally, S., Barret, B., Baray, J. L., Delmas, R., Leveau, J., Metzger, J. M., Mahieu, E., Boone, C., Walker, K. A., Bernath, P. F., and Strong, K.: Technical Note: New ground-based FTIR measurements at Ile de La Réunion: observations, error analysis, and comparisons with independent data, Atmos. Chem. Phys., 8, 3483-3508, 2008, http://www.atmos-chem-phys.net/8/3483/2008/.

Shettle, E. P.: Models of aerosols, clouds, and precipitation for atmospheric propagation studies, AGARD Conference Proceedings No. 454: Atmospheric propagation in the UV, visible, IR and mm-region and related system aspects, 1989.

Spivakovsky, C. M., Logan, J. A., Montzka, S. A., Balkanski, Y. J., Foreman-Fowler, M., Jones, D. B. A., Horowitz, L. W., A. C., Fusco, Brenninkmeijer, C. A. M., Prather, M. J., Wofsy, S. C., and McElroy, M. B.: Three-dimensional climatological distribution of tropospheric OH: Update and evaluation, J. Geophys. Res., 105(D7), 8931-8980, 2000.

Stavrakou, T., Müller, J.-F., De Smedt, I., Van Roozendael, M., van der Werf, G. R., Giglio, L., and Guenther, A.: Evaluating the performance of pyrogenic and biogenic emission inventories against one decade of space-based formaldehyde columns, Atmos. Chem. Phys., 9, 1037-1060, 2009a,

http://www.atmos-chem-phys.net/9/1037/2009/.

Stavrakou, T., Müller, J.-F., De Smedt, I., Van Roozendael, M., van der Werf, G. R., Giglio, L., and Guenther, A.: Global emissions of non-methane hydrocarbons deduced from SCIAMACHY formaldehyde columns through 2003-2006, Atmos. Chem. Phys., 9, 3663-3679, 2009b,

http://www.atmos-chem-phys.net/9/3663/2009/. 
Steck, T.: Methods for determining regularization for atmospheric retrieval problems, Appl. Optics, 41, 1788-1797, 2002.

Steck, T., Glatthor, N., von Clarmann, T., Fischer, H., Flaud, J. M., Funke, B., Grabowski, U., Höpfner, M., Kellmann, S., Linden, A., Perrin, A., and Stiller, G. P.: Retrieval of global upper tropospheric and stratospheric formaldehyde $\left(\mathrm{H}_{2} \mathrm{CO}\right)$ distributions from high-resolution MIPAS-Envisat spectra, Atmos. Chem. Phys., 8, 463-470, 2008, http://www.atmos-chem-phys.net/8/463/2008/.

Stohl, A., Forster, C., Frank, A., Seibert, P., and Wotawa, G.: Technical note: The Lagrangian particle dispersion model FLEXPART version 6.2, Atmos. Chem. Phys., 5, 2461-2474, 2005, http://www.atmos-chem-phys.net/5/2461/2005/.

Sussmann, R., Borsdorff, T., Rettinger, M., Camy-Peyret, C., Demoulin, P., Duchatelet, P., Mahieu, E., and Servais, C.: Technical Note: Harmonized retrieval of column-integrated atmospheric water vapor from the FTIR network - first examples for longterm records and station trends, Atmos. Chem. Phys., 9, 89878999, 2009, http://www.atmos-chem-phys.net/9/8987/2009/.

Taupin, F. G., Bessafi, M., Baldy, S., and Bremaud, P. J.: Tropospheric ozone above the southwestern Indian Ocean is strongly linked to dynamical conditions prevailing in the tropics, J. Geophys. Res., 104, 8057-8066, 1999.

Tejwani, G. D. T. and Yeung, E. S.: Pressure-broadened linewidths of formaldehyde, J. Chem. Phys., 66, 4915-4918, 1977.

Theys, N., Van Roozendael, M., Hendrick, F., Fayt, C., Hermans, C., Baray, J.-L., Goutail, F., Pommereau, J.-P., and De Mazière, M.: Retrieval of stratospheric and tropospheric $\mathrm{BrO}$ columns from multi-axis DOAS measurements at Réunion Island $\left(21^{\circ} \mathrm{S}\right.$, $56^{\circ}$ E), Atmos. Chem. Phys., 7, 4733-4749, 2007,

http://www.atmos-chem-phys.net/7/4733/2007/.

Tikhonov, A.: On the solution of incorrectly stated problems and a method of regularization, Dokl. Acad. Nauk SSSR, 151, 501504, 1963.

Vandaele, A.-C., Hermans, C., Simon, P. C., Carleer, M., Colin, R., Fally, S., Mérienne, M.-F., Jenouvrier, A., and Coquart, B.: Measurements of the $\mathrm{NO}_{2}$ absorption cross-section from $42000 \mathrm{~cm}^{-1}$ to $10000 \mathrm{~cm}^{-1}(238-1000 \mathrm{~nm})$ at $220 \mathrm{~K}$ and 294 K, J. Quant. Spectrosc. Radiat. T., 59, 171-184, 1997.

van der Werf, G. R., Randerson, J. T., Giglio, L., Collatz, G. J., Kasibhatla, P. S., and Arellano Jr., A. F.: Interannual variability in global biomass burning emissions from 1997 to 2004, Atmos. Chem. Phys., 6, 3423-3441, 2006,

http://www.atmos-chem-phys.net/6/3423/2006/.
Van Roozendael, M., Fayt, C., Lambert, J.-C., Pundt, I., Wagner, T., Richter, A., and Chance, K.: Development of a bromine oxide product from GOME, in Proc. ESAMS'99, WPP-161, 543-547, 1999.

Vountas, M., Rozanov, V. V., and Burrows, J. P.: Ring effect: Impact of rotational raman scattering on radiative transfer in earth's atmosphere, J. Quant. Spectrosc. Radiat. T., 60, 943-961, 1998.

Wagner, V., von Glasow, R., Fischer, H., and Crutzen, P. J.: Are $\mathrm{CH}_{2} \mathrm{O}$ measurements in the marine boundary layer suitable for testing the current understanding of $\mathrm{CH}_{4}$ photooxidation?: A model study, J. Geophys. Res., 107, D34029, doi:10.1029/2001JD000722, 2002.

Wagner, T., Dix, B., Friedeburg, C. v., Frieß, U., Sanghavi, S., Sinreich, R., and Platt, U.: MAX-DOAS $\mathrm{O}_{4}$ measurements: A new technique to derive information on atmospheric aerosols - Principles and information content, J. Geophys. Res., 109, D22205, doi:10.1029/2004JD004904, 2004.

Wagner, T., Burrows, J. P., Deutschmann, T., Dix, B., von Friedeburg, C., Frieß, U., Hendrick, F., Heue, K.-P., Irie, H., Iwabuchi, H., Kanaya, Y., Keller, J., McLinden, C. A., Oetjen, H., Palazzi, E., Petritoli, A., Platt, U., Postylyakov, O., Pukite, J., Richter, A., van Roozendael, M., Rozanov, A., Rozanov, V., Sinreich, R., Sanghavi, S., and Wittrock, F.: Comparison of box-airmass-factors and radiances for Multiple-Axis Differential Optical Absorption Spectroscopy (MAX-DOAS) geometries calculated from different UV/visible radiative transfer models, Atmos. Chem. Phys., 7, 1809-1833, 2007, http://www.atmos-chem-phys.net/7/1809/2007/.

Wang, P., Stammes, P., van der A, R., Pinardi, G., and van Roozendael, M.: FRESCO+: an improved $\mathrm{O}_{2}$ A-band cloud retrieval algorithm for tropospheric trace gas retrievals, Atmos. Chem. Phys., 8, 6565-6576, 2008, http://www.atmos-chem-phys.net/8/6565/2008/.

Wilmouth, D. M., Hanisco, T. F., Donahue, N. M., and Anderson, J. G.: Fourier transform ultraviolet spectroscopy of the $A_{3 / 2}^{2 \pi} \leftarrow X_{3 / 2}^{2 \pi}$ transition of BrO, J. Phys. Chem. A., 103, 89358945, 1999.

Wittrock, F., Richter, A., Oetjen, H., Burrows, J. P., Kanakidou, M., Myriokefalitakis, S., Volkamer, R., Beirle, S., Platt, U., and Wagner, T.: Simultaneous global observations of glyoxal and formaldehyde from space, Geophys. Res. Lett., 33, L16804, doi:10.1029/2006GL026310, 2006. 